\title{
Thallium Sorption onto Manganese Oxides
}

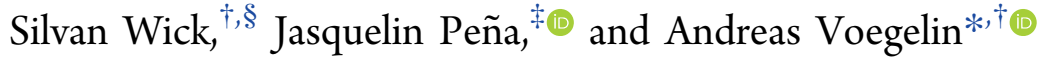 \\ ${ }^{\dagger}$ Eawag, Swiss Federal Institute of Aquatic Science and Technology, Üeberlandstrasse 133, CH-8600 Dübendorf, Switzerland \\ ${ }^{\ddagger}$ Institute of Earth Surface Dynamics, Faculty of Geosciences and Environment, University of Lausanne, CH-1015 Lausanne, \\ Switzerland \\ ${ }^{\S}$ Institute of Biogeochemistry and Pollutant Dynamics, ETH Zürich, CH-8092 Zürich, Switzerland
}

\section{Supporting Information}

\begin{abstract}
The sorption of thallium ( $\mathrm{Tl}$ ) onto manganese ( $\mathrm{Mn}$ ) oxides critically influences its environmental fate and geochemical cycling and is also of interest in water treatment. Combined quantitative and mechanistic understanding of $\mathrm{Tl}$ sorption onto $\mathrm{Mn}$ oxides, however, is limited. We investigated the uptake of dissolved $\mathrm{Tl}(\mathrm{I})$ by environmentally relevant phyllo- and tectomanganates and used X-ray absorption spectroscopy to determine the oxidation state and local coordination of sorbed $\mathrm{Tl}$. We show that extremely strong sorption of $\mathrm{Tl}$ onto vacancy-containing layered $\delta$ - $\mathrm{MnO}_{2}$ at low dissolved $\mathrm{Tl}(\mathrm{I})$ concentrations $\left(\log K_{\mathrm{d}} \geq 7.4\right.$ for $\leq 10^{-8} \mathrm{M} \mathrm{Tl}(\mathrm{I}) ; K_{\mathrm{d}}$ in $(\mathrm{L} / \mathrm{kg})$ ) is due to oxidative uptake of $\mathrm{Tl}$ and that less specific nonoxidative Tl uptake only becomes dominant at very high $\mathrm{Tl}(\mathrm{I})$ concentrations $\left(>10^{-6} \mathrm{M}\right)$.

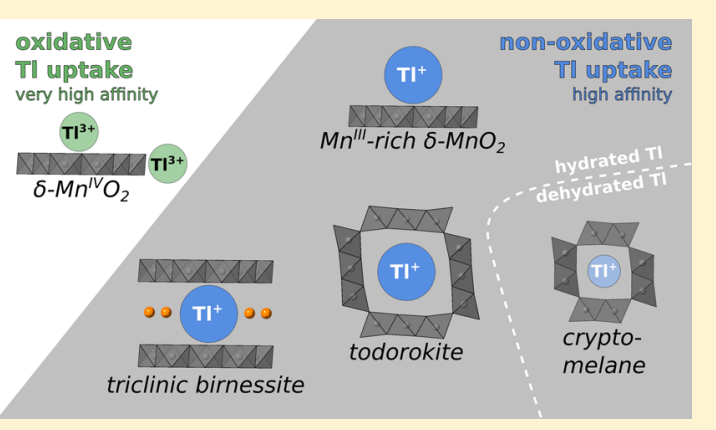
Partial reduction of $\delta$ - $\mathrm{MnO}_{2}$ induces phase changes that result in inhibited oxidative $\mathrm{Tl}$ uptake and lower $\mathrm{Tl}$ sorption affinity $\left(\log K_{\mathrm{d}} 6.2-6.4\right.$ at $\left.10^{-8} \mathrm{M} \mathrm{Tl}(\mathrm{I})\right)$ and capacity. Triclinic birnessite, which features no vacancy sites, and todorokite, a $3 \times 3$ tectomanganate, bind $\mathrm{Tl}$ with lower sorption affinity than $\delta-\mathrm{MnO}_{2}$, mainly as hydrated $\mathrm{Tl}^{+}$in interlayers (triclinic birnessite; log $K_{\mathrm{d}} 5.5$ at $10^{-8} \mathrm{M} \mathrm{Tl}(\mathrm{I})$ ) or tunnels (todorokite). In cryptomelane, a $2 \times 2$ tectomanganate, dehydrated $\mathrm{Tl}^{+}$replaces structural $\mathrm{K}^{+}$. The new quantitative and mechanistic insights from this study contribute to an improved understanding of the uptake of $\mathrm{Tl}$ by key $\mathrm{Mn}$ oxides and its relevance in natural and engineered systems.
\end{abstract}

\section{INTRODUCTION}

The sorption of toxic thallium $(\mathrm{Tl})$ onto manganese $(\mathrm{Mn})$ oxides strongly influences the mobility and bioavailability of $\mathrm{Tl}$ in contaminated soils and sediments ${ }^{1-8}$ and is also of interest for selective $\mathrm{Tl}$ removal from drinking and wastewater., ${ }^{9,10}$ Furthermore, $\mathrm{Tl}$ sorption onto $\mathrm{Mn}$ oxides is of high interest with respect to the sequestration of $\mathrm{Tl}$ in marine ferromanganese deposits ${ }^{4,11-13}$ and the interpretation of related stable $\mathrm{Tl}$ isotope patterns. ${ }^{3}$ Under common $\mathrm{pH}-\mathrm{Eh}$ conditions in natural waters, monovalent $\mathrm{Tl}(\mathrm{I})$ in free cationic form prevails. Because of its similar ionic radius and low hydration energy, the $\mathrm{Tl}^{+}$cation often reacts in analogy to rubidium $\left(\mathrm{Rb}^{+}\right)$and cesium $\left(\mathrm{Cs}^{+}\right)^{14}$ and can substitute for potassium $\left(\mathrm{K}^{+}\right)$in $\mathrm{K}$-bearing minerals such as $\mathrm{K}$-feldspar or mica. ${ }^{4,15,16}$ Trivalent $\mathrm{Tl}(\mathrm{III})$ forms under strongly oxidizing conditions. The $\mathrm{Tl}^{3+}$ cation hydrolyzes readily and forms poorly soluble $\mathrm{Tl}_{2} \mathrm{O}_{3}$ (avicennite). ${ }^{4,17}$ High concentrations of $\mathrm{Tl}$ in $\mathrm{Mn}$ oxides in ore deposits, marine ferromanganese nodules and crusts, and soil Mn concretions have been attributed to oxidative $\mathrm{Tl}$ uptake, nonoxidative sorption of $\mathrm{Tl}^{+}$, or substitution of structural $\mathrm{K}^{+}$by $\mathrm{Tl}^{+}$, depending on the type of Mn oxide. ${ }^{8,11,18}$

Birnessite-like $\mathrm{Mn}$ oxides are highly reactive minerals and form in the environment by microbial or autocatalytic oxidation. ${ }^{19}$ They are composed of stacks of octahedral
$\mathrm{MnO}_{2}$ sheets and are differentiated based on the vacancy and $\mathrm{Mn}(\mathrm{III})$ content of the octahedral sheets, layer symmetry, and the extent of layer stacking. ${ }^{20}$ Synthetic $\delta$ - $\mathrm{MnO}_{2}$ consists of turbostratically stacked hexagonal $\mathrm{MnO}_{2}$ sheets that contain mainly $\mathrm{Mn}(\mathrm{IV})$, with a negative layer charge arising mainly from $\mathrm{Mn}$ vacancies or $\mathrm{Mn}(\mathrm{III}){ }^{21} \delta-\mathrm{MnO}_{2}$ is highly reactive and considered to be a synthetic analogue to biogenic $\mathrm{Mn}$ oxides and vernadite. ${ }^{19,20}$ Using X-ray absorption spectroscopy (XAS), Tl uptake by $\delta$ - $\mathrm{MnO}_{2}$ has been shown to involve the oxidation of $\mathrm{Tl}(\mathrm{I})$ to $\mathrm{Tl}(\mathrm{III}){ }^{22}$ By comparing the mode of $\mathrm{Tl}$ uptake by vacancy-containing hexagonal birnessite and vacancy-free triclinic birnessite, Peacock and Moon $(2012)^{11}$ concluded that oxidative $\mathrm{Tl}$ uptake requires the presence of vacancy sites on top of which $\mathrm{Tl}$ (III) is bound. Nonoxidative uptake of $\mathrm{Tl}(\mathrm{I})$ by triclinic birnessite, which bears a negative charge arising from $\mathrm{Mn}(\mathrm{III})$ in the $\mathrm{MnO}_{2}$ layers, was attributed to outer-sphere $\mathrm{Tl}(\mathrm{I})$ binding. ${ }^{11}$ In another study with vacancy-containing $\delta$ - $\mathrm{MnO}_{2}$ and acid birnessite, oxidative Tl uptake was suggested to occur through complexation of $\mathrm{Tl}$ (III) at edge sites at particle edges in addition to sorption onto

Received: July 24, 2019

Revised: October 11, 2019

Accepted: October 17, 2019

Published: November 1, 2019 
vacancy sites. ${ }^{23}$ Although recent studies provided insights into possible uptake mechanisms of $\mathrm{Tl}$ on layered Mn oxides, ${ }^{11,23}$ structural information was either not combined with sorption data or was limited to samples with very high Tl loadings.

Layered $\mathrm{Mn}(\mathrm{IV})$ oxides such as $\delta-\mathrm{MnO}_{2}$ can be reduced by the reaction with organic ${ }^{24-27}$ or inorganic ${ }^{28-31}$ reductants, leading to the release of $\mathrm{Mn}$ (III) into the interlayer and the blocking of vacancy sites by $\mathrm{Mn}(\mathrm{III}){ }^{24,30,31}$ The production of $\mathrm{Mn}(\mathrm{III})$ in $\delta-\mathrm{MnO}_{2}$ can substantially alter the reactivity of the oxide, depending also on the type of sorbing cation. ${ }^{32-38}$ Furthermore, (partially reduced) layered $\mathrm{Mn}$ oxides can transform into tectomanganates over time. Todorokite, a tectomanganate with $3 \times 3 \mathrm{Mn}$-octahedra-wide tunnels, is commonly found in the marine environment due to the structure determining effect of hydrated magnesium $\left(\mathrm{Mg}^{2+}\right){ }^{39-43}$ Cryptomelane, a tectomanganate with $2 \times 2$ tunnels, forms mainly in terrestrial environments under the influence of readily dehydrating $\mathrm{K}^{+} \cdot{ }^{44-47}$ For todorokite, XAS data point to outer-sphere sorption of hydrated $\mathrm{Tl}(\mathrm{I}) .{ }^{11}$ High contents of $\mathrm{Tl}$ in cryptomelane, on the other hand, have been attributed to substitution of structural $\mathrm{K}^{+}$by $\mathrm{Tl}^{+}{ }^{18}$ Sorption data for $\mathrm{Tl}(\mathrm{I})$ on partially reduced $\delta-\mathrm{MnO}_{2}$ and tectomanganates have not been determined to date.

Previous studies have indicated that the mode of $\mathrm{Tl}$ sorption onto $\mathrm{Mn}$ oxides depends on the characteristics of the Mn oxide. However, combined mechanistic and quantitative information on $\mathrm{Tl}$ sorption onto key $\mathrm{Mn}$ oxides over environmentally relevant concentration ranges is still scarce. In this study, we therefore studied the sorption of $\mathrm{Tl}$ onto sodium- (Na-), potassium- (K-), and calcium- (Ca-)exchanged $\delta$ - $\mathrm{MnO}_{2}$, partially reduced $\delta$ - $\mathrm{MnO}_{2}$, triclinic birnessite, todorokite, and cryptomelane in batch experiments and used XAS to assess the oxidation state and local coordination of sorbed Tl. The new insights from this work support the assessment of the role of $\mathrm{Tl}$ sorption onto $\mathrm{Mn}$ oxides in natural and technical systems over a wide range of conditions.

\section{MATERIALS AND METHODS}

Mn Oxides. Details on the synthesis of the Mn oxides are provided in the Supporting Information (Section 1). Briefly, $\delta$ $\mathrm{MnO}_{2}$ was synthesized by reacting $\mathrm{KMnO}_{4}$ with $\mathrm{MnCl}_{2}{ }^{21,48}$ The washed precipitate was exchanged with $\mathrm{Na}\left(\mathrm{Na}-\delta-\mathrm{MnO}_{2}\right.$; $\left.0.1 \mathrm{M} \mathrm{NaNO}_{3}\right), \mathrm{K}\left(\mathrm{K}-\delta-\mathrm{MnO}_{2} ; 0.1 \mathrm{M} \mathrm{KNO}_{3}\right)$, or $\mathrm{Ca}(\mathrm{Ca}-\delta$ $\left.\mathrm{MnO}_{2} ; 0.01 \mathrm{M} \mathrm{Ca}\left(\mathrm{NO}_{3}\right)_{2}\right)$. Half of each batch was washed with double deionized (DDI) water and freeze-dried, and the other half was stored as suspension at $4{ }^{\circ} \mathrm{C}$ in the dark. Triclinic birnessite was synthesized by reacting $\mathrm{Mn}\left(\mathrm{NO}_{3}\right)_{2}$ with $\mathrm{H}_{2} \mathrm{O}_{2}$. ${ }^{11}$ The fresh precipitate was exchanged with $\mathrm{Na}$. Todorokite was synthesized by hydrothermal reaction of birnessite with $\mathrm{Mg}^{49}$ and exchanged with $\mathrm{Mg}$. Cryptomelane was synthesized by reacting a boiling $\mathrm{KMnO}_{4}$ solution with $\mathrm{HCl}$, followed by hydrothermal treatment, ${ }^{50}$ and exchanged with $\mathrm{K}$. Three partially reduced $\delta-\mathrm{MnO}_{2}$ were obtained by reacting $\mathrm{Na}-\delta-\mathrm{MnO}_{2}$ with either hydroquinone ( $\mathrm{HQ}-\delta-\mathrm{MnO}_{2}$; final synthesis $\mathrm{pH}$ of 8.7), ${ }^{51,52}$ HEPES buffer (HEPES- $\delta$ $\mathrm{MnO}_{2}$; final synthesis $\mathrm{pH}$ of 6.7$),{ }^{29,36}$ or dissolved $\mathrm{Fe}(\mathrm{II})$ $\left(\mathrm{Fe}(\mathrm{II})-\delta-\mathrm{MnO}_{2}\right.$; final synthesis $\mathrm{pH}$ of 2.9$) .{ }^{53}$ Finally, the solids were washed, freeze-dried, and stored in the dark at room temperature.

Characterization of $\mathrm{Mn}$ Oxides. The $\mathrm{Mn}$ oxides were analyzed for their mineralogy (X-ray diffraction; XRD), specific surface area (SSA; measured by $\mathrm{N}_{2}$ adsorption $\left(\mathrm{N}_{2}-\mathrm{BET}\right)$; Quantachrome NovaWin), average manganese oxidation number (AMON; measured by potentiometric titration), ${ }^{54-56}$ and elemental composition (digestion of $\mathrm{Mn}$ oxide samples with oxalic and nitric acid; analysis of digests using an inductively coupled plasma mass spectrometer (ICP-MS; Agilent Triple Quadrupole 8900)). AMON titrations and digestions were performed at least in duplicates. Selected samples were imaged using scanning transmission electron microscopy (STEM).

Sorption Experiments. Details are given in the Supporting Information (Section 2). Briefly, the $\mathrm{Mn}$ oxides were suspended in the background electrolyte $\left(\mathrm{Na}-\delta-\mathrm{MnO}_{2}\right.$, partially reduced $\delta-\mathrm{MnO}_{2}$, and triclinic birnessite: $0.1 \mathrm{M}$ $\mathrm{NaNO}_{3} ; \mathrm{K}-\delta-\mathrm{MnO}_{2}: 0.1 \mathrm{M} \mathrm{KNO}_{3} ; \mathrm{Ca}-\delta-\mathrm{MnO}_{2}: 0.01 \mathrm{M}$ $\mathrm{Ca}\left(\mathrm{NO}_{3}\right)_{2}$; todorokite: $0.01 \mathrm{M} \mathrm{Mg}\left(\mathrm{NO}_{3}\right)_{2}$; and cryptomelane: $0.01 \mathrm{M} \mathrm{KNO}_{3}$ ) and sonicated for $20 \mathrm{~min}$. A $0.01 \mathrm{M} \mathrm{TlNO}_{3}$ stock solution was prediluted in half of the final volume of the background electrolyte (i.e., at twice the intended initial $\mathrm{Tl}$ concentrations from $\sim 7.5 \times 10^{-5}$ to $\left.7.5 \times 10^{-3} \mathrm{M}\right)$ to avoid the direct reaction between suspended $\mathrm{Mn}$ oxides and the concentrated stock solution during spiking. After mixing of the Tl-containing solution and $\mathrm{Mn}$ oxide suspension and adjusting the final volume, the suspensions contained $\sim 3-5 \mathrm{~g} / \mathrm{L}$ dried Mn oxide or $\sim 7 \mathrm{~g} / \mathrm{L}$ fresh $\delta-\mathrm{MnO}_{2}(\sim 25-70 \mathrm{mM} \mathrm{Mn})$. The sorbents were reacted with $\mathrm{Tl}$ for $\sim 24 \mathrm{~h}$ in the dark at room temperature. Suspension $\mathrm{pH}$ was not adjusted with buffers or by acid/base additions to minimize unintended structural changes. The reacted suspensions were centrifuged. The supernatant was filtered ( $0.2 \mu$ m nylon membranes), acidified, and analyzed using ICP-MS. The $\mathrm{pH}$ was recorded in the remaining supernatant. The difference between spiked and residual dissolved $\mathrm{Tl}$ was assumed to be sorbed $\mathrm{Tl}$. Based on the $\mathrm{pH}-\mathrm{Eh}$ stability diagram of $\mathrm{Tl}$ (Figure S8), dissolved $\mathrm{Tl}$ was mainly free $\mathrm{Tl}^{+}$in all sorption experiments.

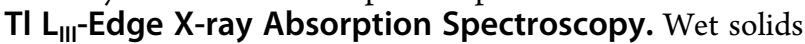
from the sorption experiments were freeze-dried, mixed with cellulose (binder), and prepared as $7 \mathrm{~mm}$ diameter pellets that were stored in the dark at room temperature. $\mathrm{Tl}_{\mathrm{LII}}$-edge $\mathrm{X}$-ray absorption near-edge structure (XANES) and extended X-ray absorption fine structure (EXAFS) spectra of Tl-sorbed Mn oxides and reference samples were collected at the SwissNorwegian Beamline (SNBL, BM31) at the European Synchrotron Radiation Facility (ESRF, Grenoble, France), the Dutch-Belgian Beamline (DUBBLE, BM26A) at the ESRF, the SAMBA (Spectroscopy Applied to Material Based on Absorption) beamline at the Synchrotron Soleil (Gif-surYvette, France), and the SuperXAS beamline at the Swiss Light Source (SLS, Villigen, Switzerland). All samples were analyzed at room temperature. In addition, selected samples were also analyzed at $20 \mathrm{~K}$ using a $\mathrm{He}$ cryostat. Samples with $\mathrm{Tl}$ concentrations up to $\sim 10,000 \mathrm{mg} / \mathrm{kg}$ were analyzed in fluorescence mode, and samples with $\mathrm{Tl}$ concentrations of $\sim 30,000 \mathrm{mg} / \mathrm{kg}$ and higher were analyzed in transmission mode. The software package Demeter ${ }^{57}$ was used for the extraction of the normalized XANES and EXAFS spectra, linear combination fitting (LCF) of the XANES spectra to determine $\mathrm{Tl}$ redox speciation, and shell fitting of selected EXAFS spectra to characterize local $\mathrm{Tl}$ coordination. Details are provided in the Supporting Information (Section 3).

\section{RESULTS}

Structure and Composition of Mn Oxide Sorbents. The properties of the Mn oxides used in this study are listed in Table 1 (further details in the Supporting Information (Section 
Table 1. Specific Surface Area (SSA), Average Coherently Scattering Domain (CSD) Size, Average Manganese Oxidation Number (AMON), Stoichiometric Chemical Composition, and Mass-Based Mn Content of the Mn Oxides Used in T1 Sorption Experiments

\begin{tabular}{|c|c|c|c|c|c|}
\hline solid & $\operatorname{SSA}\left(\mathrm{m}^{2} / \mathrm{g}\right)$ & CSD size $(n m)$ & AMON & composition $^{a}$ & Mn content $(\mathrm{mol} / \mathrm{kg})$ \\
\hline $\mathrm{Na}-\delta-\mathrm{MnO}_{2}{ }^{b}$ & 202 & 9.5 & $4.05(0.01)$ & $\mathrm{Na}_{0.20} \mathrm{~K}_{0.05} \mathrm{MnO}_{2.12} \cdot 1.49 \mathrm{H}_{2} \mathrm{O}$ & $8.2(0.8)$ \\
\hline $\mathrm{K}-\delta-\mathrm{MnO}_{2}^{b}$ & 205 & 8.0 & $4.05(0.01)$ & $\mathrm{Na}_{0.02} \mathrm{~K}_{0.22} \mathrm{MnO}_{2.12} \cdot 0.63 \mathrm{H}_{2} \mathrm{O}$ & $9.2(0.8)$ \\
\hline $\mathrm{Ca}-\delta-\mathrm{MnO}_{2}{ }^{b}$ & 250 & 7.2 & $4.03(0.01)$ & $\mathrm{Na}_{0.05} \mathrm{~K}_{0.06} \mathrm{Ca}_{0.06} \mathrm{MnO}_{2.11} \cdot 0.58 \mathrm{H}_{2} \mathrm{O}$ & $9.5(0.5)$ \\
\hline $\mathrm{HQ}-\delta-\mathrm{MnO}_{2}$ & 92 & 22 & $3.83(0.00)$ & $\mathrm{Na}_{0.29} \mathrm{MnO}_{2.06} \cdot 1.44 \mathrm{H}_{2} \mathrm{O}$ & $8.3(0.5)$ \\
\hline HEPES- $\delta-\mathrm{MnO}_{2}{ }^{c}$ & 80 & 38 & $3.79(0.01)$ & $\mathrm{Na}_{0.25} \mathrm{MnO}_{2.02} \cdot 2.28 \mathrm{H}_{2} \mathrm{O}$ & $7.5(0.8)$ \\
\hline $\mathrm{Fe}(\mathrm{II})-\delta-\mathrm{MnO}_{2}{ }^{d}$ & 140 & 24 & $3.91(0.03)$ & $\mathrm{Na}_{0.20} \mathrm{Mn}_{2.06} \cdot 1.66 \mathrm{H}_{2} \mathrm{O}$ & $8.2(0.3)$ \\
\hline triclinic birnessite & 5.4 & 14 & $3.86(0.00)$ & $\mathrm{Na}_{0.28} \mathrm{MnO}_{2.07} \cdot 1.03 \mathrm{H}_{2} \mathrm{O}$ & $8.8(0.1)$ \\
\hline todorokite & 110 & 19 & $3.74(0.00)$ & $\mathrm{Mg}_{0.11} \mathrm{MnO}_{1.98} \cdot 0.68 \mathrm{H}_{2} \mathrm{O}$ & $9.8(0.1)$ \\
\hline cryptomelane & 17 & 27 & $3.90(0.01)$ & $\mathrm{K}_{0.14} \mathrm{MnO}_{2.02}$ & $11.0(0.0)$ \\
\hline
\end{tabular}

${ }^{a}$ Composition determined by dissolving the solids in triplicates. Stoichiometry calculated as described in the Supporting Information (Section 1.6). Relative standard deviations (RSD) of the stoichiometric coefficients were in general $\leq 5 \%$, except for $\mathrm{H}_{2} \mathrm{O}$ content (RSDs up to $34 \%$ ). ${ }^{b}$ All parameters determined on the dried $\delta$ - $\mathrm{MnO}_{2}$ batches; assumed to be the same for batches stored in suspension. ${ }^{c}$ Sample HEPES- $\delta$-MnO ${ }_{2}$ contained $0.70 \pm 0.19 \mathrm{NaNO}_{3}$ per $\mathrm{Mn}(31 \% \mathrm{w} / \mathrm{w})$ (details in the Supporting Information, Sections 1.3 and 1.6). The mass-based SSA and Mn content of HEPES- $\delta$ - $\mathrm{MnO}_{2}$ and mass-based sorbed amounts (Figure $1 \mathrm{~B}$ and Table 2) refer to the mass of the Mn oxide without the associated $\mathrm{NaNO}_{3} \cdot{ }^{d}$ Sample $\mathrm{Fe}(\mathrm{II})-\delta-\mathrm{MnO}_{2}$ contained $0.34 \pm 0.04 \mathrm{Fe}(\mathrm{OH})_{3}$ per $\mathrm{Mn}(23 \% \mathrm{w} / \mathrm{w})$. The Mn content of Fe(II)- $\delta$ - $\mathrm{MnO} \mathrm{O}_{2}$ is given for the mass of $\mathrm{Mn}$ oxide alone, without the associated $\mathrm{Fe}(\mathrm{OH})_{3}$. Sorbed amounts (Figure $1 \mathrm{~B}$ and Table 2) are also expressed relative to the mass of Mn oxide alone, as sorption of $\mathrm{Tl}(\mathrm{I})$ onto ferrihydrite is negligible at $\mathrm{pH} \sim 4 .{ }^{81}$ The SSA of $\mathrm{Fe}(\mathrm{II})-\delta-\mathrm{MnO}_{2}$ relates to the mass of the Mn oxide and associated $\mathrm{Fe}(\mathrm{OH})_{3}$.

1); published data for comparison in Table S3). XRD results (Figure S1) confirmed that the intended Mn oxides were synthesized and provided information on coherently scattering domain (CSD) sizes, on the stacking of layer-type Mn oxides, and on the structure of the partially reduced $\delta-\mathrm{MnO}_{2}$.

$\delta$ - $\mathrm{MnO}_{2}$ showed no detectable stacking and had a small CSD $(\sim 8 \mathrm{~nm})$, reflected also in its high specific surface area (SSA). The AMON of Na-, K-, and $\mathrm{Ca}-\delta-\mathrm{MnO}_{2}$ was close to 4.0. The HQ- and HEPES-reacted $\delta$ - $\mathrm{MnO}_{2}$ exhibited AMON values of $\sim 3.8$, in line with the anticipated extent of $\mathrm{Mn}(\mathrm{IV})$ reduction (Supporting Information, Section 1.2). The lower specific surface areas of $\mathrm{HQ}-\delta-\mathrm{MnO}_{2}$ and HEPES- $\delta-\mathrm{MnO}_{2}$ compared to $\delta-\mathrm{MnO}_{2}$ may have been caused by changes in crystallite or particle size. A structural transformation of these partially reduced $\delta-\mathrm{MnO}_{2}$ was not expected under our experimental conditions, ${ }^{25,28,29,36,37,58}$ as confirmed by XRD (Figure S1). The XRD pattern of the $\mathrm{Fe}(\mathrm{II})$-reacted $\delta-\mathrm{MnO}_{2}$, on the other hand, showed that $\delta-\mathrm{MnO}_{2}$ had been (partly) transformed into nsutite, a $\mathrm{Mn}(\mathrm{II} / \mathrm{IV})$ tectomanganate. ${ }^{59}$ Taking into account that the reaction of $\mathrm{Fe}(\mathrm{II})$ with $\delta-\mathrm{MnO}_{2}$ resulted in a synthesis $\mathrm{pH}$ of 2.9, the observed formation of nsutite from $\delta$ - $\mathrm{MnO}_{2}$ was in agreement with a recent study showing that proton-promoted $\mathrm{Mn}(\mathrm{III})$ disproportionation ${ }^{60}$ drives the transformation of hausmannite into $\delta-\mathrm{MnO}_{2}$ and finally nsutite in $\mathrm{Na}$ electrolyte at $\mathrm{pH} 3.0 .^{61}$ For triclinic birnessite, a CSD size of $\sim 14 \mathrm{~nm}$ perpendicular to the basal surface (peak at $12.54^{\circ}$, Table S2) suggests that individual crystallites consist of $\sim 20$ stacked layers. This was qualitatively in line with particle morphology probed by STEM (Figure $\mathrm{S} 5 \mathrm{~A}$ ) and the much lower surface area as compared to $\delta$ $\mathrm{MnO}_{2}$. The AMON of triclinic birnessite (3.86) corresponds to a $\mathrm{Mn}(\mathrm{III})$ content of about $14 \%$ of the total $\mathrm{Mn}$. The composition, surface area, and AMON of todorokite and cryptomelane fell into the range of published values (Table S3).

Sorption Isotherms. Log-scale isotherms for $\mathrm{Tl}$ sorption onto all studied $\mathrm{Mn}$ oxides are displayed in Figure $1 \mathrm{~A}-\mathrm{C}$. The relations between the log-transformed amounts of sorbed $\mathrm{Tl}$ $(\log (\mathrm{Q} /(\mathrm{mol} / \mathrm{kg}), \quad Q$ in $\mathrm{mol} / \mathrm{kg})$ and the log-transformed dissolved $\mathrm{Tl}$ concentrations $(\log (C /(\mathrm{M}), \quad C$ in $\mathrm{M})$ were described by linear regressions according to $\log (Q /(\mathrm{mol} /$ $\mathrm{kg}))=\log K_{\mathrm{f}}+n \times \log (\mathrm{C} /(\mathrm{M}))$, equivalent to log-transformed Freundlich isotherms. Based on the linear regression parameters, log-transformed distribution coefficients $\left(\log \left(K_{\mathrm{d}} /\right.\right.$ $(\mathrm{L} / \mathrm{kg}))=\log (\mathrm{Q} /(\mathrm{mol} / \mathrm{kg})-\log (\mathrm{C} /(\mathrm{M})))$ were calculated for selected dissolved $\mathrm{Tl}$ concentrations $\mathrm{C}$ according to $\log \left(K_{\mathrm{d}} /(\mathrm{L} / \mathrm{kg})\right)=\log K_{\mathrm{f}}+(n-1) \times \log (C /(\mathrm{M}))$. For all sorption experiments, the electrolyte cation type and concentration, the final solution $\mathrm{pH}$ value, linear regression parameters and calculated $\log K_{\mathrm{d}}$ values for selected $\mathrm{Tl}$ concentrations are listed in Table 2.

The sorption isotherms for $\delta$ - $\mathrm{MnO}_{2}$ and triclinic birnessite cover about seven orders of magnitude in dissolved $\mathrm{Tl}$ concentrations (Figure 1A). For $\delta$ - $\mathrm{MnO}_{2}$, the data revealed no clear differences between $\mathrm{Na}-, \mathrm{K}$-, and $\mathrm{Ca}$-exchanged $\delta$ $\mathrm{MnO}_{2}$ or between fresh and dried $\delta-\mathrm{MnO}_{2}$. The linear regression equation over all log-scale sorption data for $\delta-\mathrm{MnO}_{2}$ exhibited a slope of only $\sim 0.2$, corresponding to an increase in dissolved $\mathrm{Tl}$ by five orders of magnitude over an increase in sorbed $\mathrm{Tl}$ by a factor of 10 . In contrast, the sorption isotherm for $\mathrm{Tl}$ on triclinic birnessite exhibited a slope of $\sim 0.8$. In comparison to $\delta-\mathrm{MnO}_{2}$, orders of magnitude lower amounts of Tl (per sorbent mass) were sorbed onto triclinic birnessite at low dissolved $\mathrm{Tl}$ concentrations $\left(\sim 10^{-10} \mathrm{M}\right)$, whereas sorbed amounts at the highest $\mathrm{Tl}$ concentrations $\left(\sim 10^{-4} \mathrm{M}\right)$ were comparable. In terms of distribution coefficients (log $K_{\mathrm{d}}$, Figure 1D), these trends correspond to a much higher sorption affinity of $\mathrm{Tl}$ for $\delta$ - $\mathrm{MnO}_{2}$ than triclinic birnessite at the lowest probed $\mathrm{Tl}$ concentrations, a strong decrease in $\mathrm{Tl}$ sorption affinity to $\delta-\mathrm{MnO}_{2}$ with increasing $\mathrm{Tl}$ concentration, and similar sorption affinities for $\delta-\mathrm{MnO}_{2}$ and triclinic birnessite at the highest probed $\mathrm{Tl}$ concentrations.

The sorption isotherms for $\mathrm{Tl}$ binding onto partially reduced $\delta-\mathrm{MnO}_{2}$ revealed a decrease in sorption affinity relative to unreacted $\delta-\mathrm{MnO}_{2}$. Among the partially reduced $\delta-\mathrm{MnO}_{2}$, sorption was the highest for $\mathrm{HQ}-\delta$ - $\mathrm{MnO}_{2}$ and similar for HEPES- $\delta$ - $\mathrm{MnO}_{2}$ and $\mathrm{Fe}(\mathrm{II})-\delta-\mathrm{MnO}_{2}$ (Figure 1B). Tl sorption onto todorokite followed an isotherm with a slope similar to $\mathrm{Tl}$ sorption onto $\delta$ - $\mathrm{MnO}_{2}$ but at about 10-fold lower loading (Figure 1C). For cryptomelane, the log-scale isotherm 

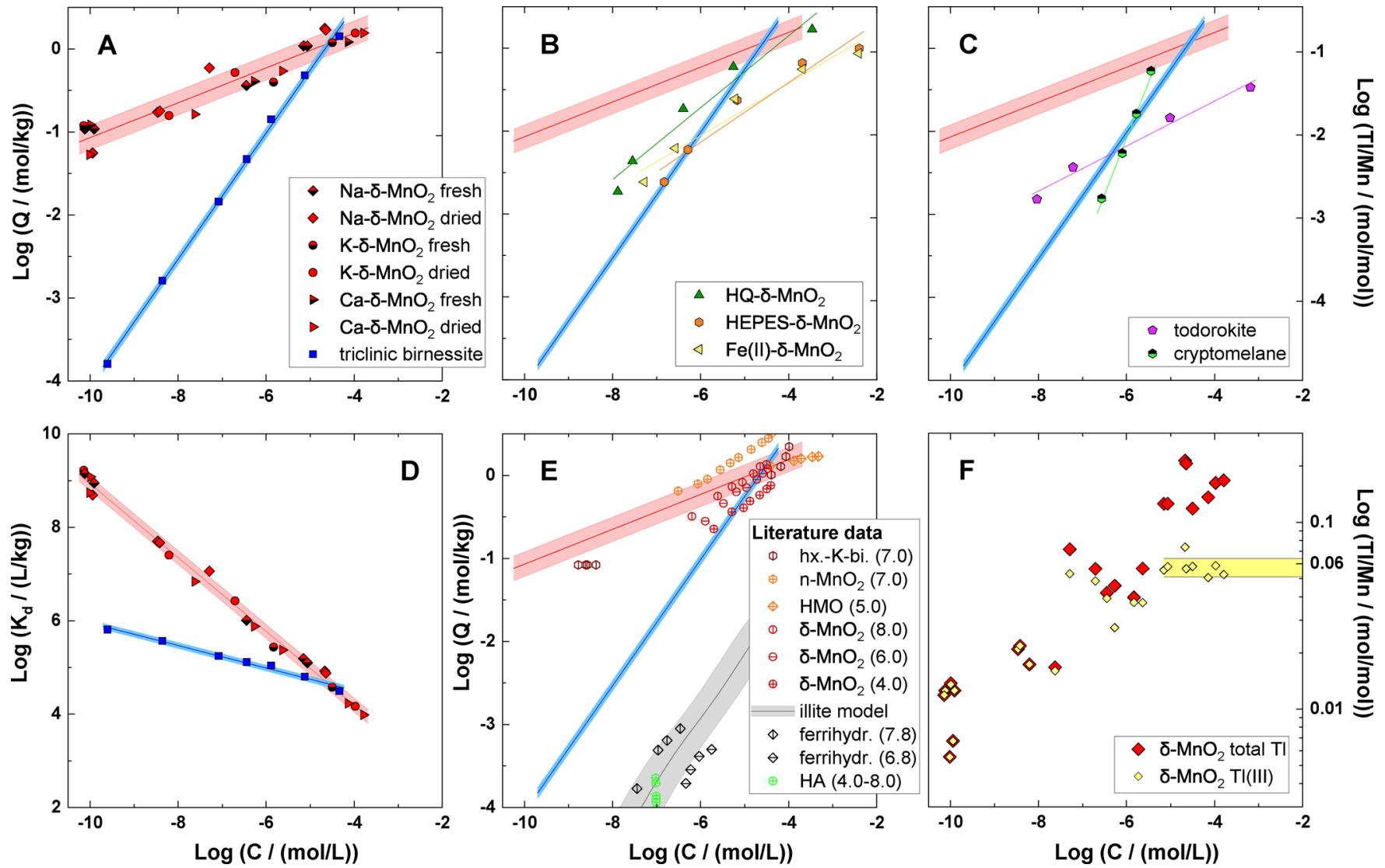

Figure 1. Sorption of $\mathrm{Tl}$ onto (A) $\delta$ - $\mathrm{MnO}_{2}$ and triclinic birnessite, (B) partially reduced HQ-, HEPES-, and $\mathrm{Fe}(\mathrm{II})-\delta$-MnO ${ }_{2}$, and (C) cryptomelane and todorokite. The logarithm of sorbed $\mathrm{Tl}$ is given in $\mathrm{mol} / \mathrm{kg}$ (left axis) and as a molar $\mathrm{Tl} / \mathrm{Mn}$ ratio (right axis, for an average $\mathrm{Mn}$ content of $\mathrm{Mn}$ oxides of $9.0 \mathrm{~mol} / \mathrm{kg}$ ). Lines represent the linear regression equations listed in Table 2 . The regression equations including the uncertainty band for $\delta$ - $\mathrm{MnO}_{2}$ and triclinic birnessite are shown in all panels for comparison. (D) Sorption of $\mathrm{Tl}$ onto $\delta-\mathrm{MnO}_{2}$ and triclinic birnessite expressed as logtransformed distribution coefficient $K_{\mathrm{d}}=Q / C$ (straight lines calculated from regressions in Table 2). (E) Comparison of regression lines for Tl sorption onto $\delta-\mathrm{MnO}_{2}$ and triclinic birnessite with published data for Tl sorption onto various sorbents ( $\mathrm{pH}$ in parentheses): vacancy-containing layered $\mathrm{Mn}$ oxides (hexagonal K-birnessite (hx. K-bi), ${ }^{3}$ nano- $\mathrm{MnO}_{2}\left(\mathrm{n}-\mathrm{MnO}_{2}\right),{ }^{9}$ amorphous hydrous manganese dioxide (HMO), ${ }^{10}$ and $\delta$ $\mathrm{MnO}_{2}{ }^{23}$ ), illite (calculated for arable soil solution), ${ }^{14}$ ferrihydrite (ferrihydr.), ${ }^{76}$ and humic acids (HA) ${ }^{75}$ (F) Total sorbed $\mathrm{Tl}$ and sorbed $\mathrm{Tl}(\mathrm{III})$ on $\delta$ - $\mathrm{MnO}_{2}$, expressed as a molar $\mathrm{Tl} / \mathrm{Mn}$ ratio (based on LCF results; Table S14). The yellow band represents average $\mathrm{Tl}(\mathrm{III})$ and standard deviation of the eight samples with the highest loadings.

Table 2. Sorption Experiments: Electrolyte Cation Type and Concentration and Final pH (after Sorption), Parameters of Linear Regressions Describing the Sorption of Tl onto Individual Mn Oxides (Figure 1A-C), Logarithm of the Distribution Coefficient $K_{d}\left(\right.$ in $(\mathrm{L} / \mathrm{kg})$ ) Calculated from the Linear Regressions for Dissolved Tl Concentrations $C$ of $10^{-8}$ and $10^{-5} \mathrm{M}^{-}$

\begin{tabular}{|c|c|c|c|c|c|c|c|c|}
\hline \multirow[b]{2}{*}{ Mn oxide } & \multicolumn{2}{|c|}{ experimental conditions } & \multicolumn{4}{|c|}{ linear regression parameters ${ }^{a}$} & \multicolumn{2}{|c|}{ calculated $\log K_{\mathrm{d}}^{b}$} \\
\hline & electrolyte cation & $\mathrm{pH}$ after sorption ${ }^{c}$ & $n_{\mathrm{DP}}$ & $\log K_{\mathrm{f}}$ & $\overline{n_{\mathrm{f}}}$ & $R^{2}$ & $\left(C=10^{-8} \mathrm{M}\right)$ & $\left(C=10^{-5} \mathrm{M}\right)$ \\
\hline $\mathrm{Na}-\delta-\mathrm{MnO}_{2}$ & $0.1 \mathrm{M} \mathrm{Na}$ & $6.8(0.2)$ & 11 & $1.27(0.15)$ & $0.23(0.02)$ & 0.94 & 7.4 & 5.1 \\
\hline $\mathrm{K}-\delta-\mathrm{MnO}_{2}$ & $0.1 \mathrm{M} \mathrm{K}$ & $6.9(0.1)$ & 6 & $0.86(0.19)$ & $0.19(0.03)$ & 0.92 & 7.4 & 4.9 \\
\hline $\mathrm{Ca}-\delta-\mathrm{MnO}_{2}$ & $0.01 \mathrm{M} \mathrm{Ca}$ & $5.1(0.3)$ & 7 & $0.91(0.15)$ & $0.21(0.02)$ & 0.95 & 7.3 & 4.9 \\
\hline$\delta-\mathrm{MnO}_{2}{ }^{d}$ & & $6.3(0.8)$ & 24 & $1.03(0.10)$ & $0.21(0.01)$ & 0.92 & 7.4 & 5.0 \\
\hline $\mathrm{HQ}-\delta-\mathrm{MnO}_{2}$ & $0.1 \mathrm{M} \mathrm{Na}$ & $7.4(0.2)$ & 5 & $1.88(0.35)$ & $0.43(0.05)$ & 0.95 & 6.4 & 4.7 \\
\hline HEPES- $\delta-\mathrm{MnO}_{2}$ & $0.1 \mathrm{M} \mathrm{Na}$ & $6.6(0.3)$ & 5 & $1.03(0.28)$ & $0.36(0.05)$ & 0.94 & 6.1 & 4.2 \\
\hline $\mathrm{Fe}(\mathrm{II})-\delta-\mathrm{MnO}_{2}$ & $0.1 \mathrm{M} \mathrm{Na}$ & $4.1(0.1)$ & 5 & $0.84(0.23)$ & $0.32(0.04)$ & 0.95 & 6.3 & 4.3 \\
\hline triclinic birnessite & $0.1 \mathrm{M} \mathrm{Na}$ & $9.1(0.4)$ & 7 & $3.54(0.10)$ & $0.76(0.01)$ & 1.00 & 5.5 & 4.7 \\
\hline todorokite & $0.01 \mathrm{M} \mathrm{Mg}$ & $5.6(0.5)$ & 4 & $0.45(0.17)$ & $0.27(0.03)$ & 0.98 & 6.3 & 4.1 \\
\hline cryptomelane & $0.01 \mathrm{M} \mathrm{K}^{\circ}$ & $8.4(0.6)$ & 4 & $7.03(0.49)$ & $1.35(0.08)$ & 0.99 & 4.2 & 5.3 \\
\hline
\end{tabular}

${ }^{a}$ Parameters for the linear regression equation $\log (\mathrm{Q} /(\mathrm{mol} / \mathrm{kg}))=\log K_{\mathrm{f}}+n_{\mathrm{f}} \times \log (\mathrm{C} / \mathrm{M})$, where $Q$ represents sorbed $\mathrm{Tl}($ in $\mathrm{mol} / \mathrm{kg})$ and $C$ represents dissolved $\mathrm{Tl}$ (in M). This equation corresponds to the logarithmic form of the Freundlich isotherm equation $Q /(\mathrm{mol} / \mathrm{kg})=K_{\mathrm{f}} \times(C /$ $\mathrm{M})^{n_{\mathrm{f}}}$. The parameters $\log K_{\mathrm{f}}$ and $n_{\mathrm{f}}$ were refined by minimizing the sum of the squared residuals (with standard errors in parentheses). $n_{\mathrm{DP}}:$ number of data points; $R^{2}$ : coefficient of determination. ${ }^{b} \log \left(K_{\mathrm{d}} /(\mathrm{L} / \mathrm{kg})\right)$ calculated for selected dissolved Tl concentrations according to $\log \left(K_{\mathrm{d}} /(\mathrm{L} / \mathrm{kg})\right)$ $=\log K_{\mathrm{f}}+\left(n_{\mathrm{f}}-1\right) \times \log (C / \mathrm{M}) .{ }^{c}$ Average $\mathrm{pH}$ (and standard deviation in parentheses) of $\mathrm{pH}$ recorded for individual Tl loadings (Tables S5-S11). ${ }^{d}$ Linear regression over all data points for dried and fresh $\mathrm{Na}-\delta-\mathrm{MnO}_{2}, \mathrm{~K}-\delta-\mathrm{MnO}_{2}$, and $\mathrm{Ca}-\delta-\mathrm{MnO}_{2}$. 
A

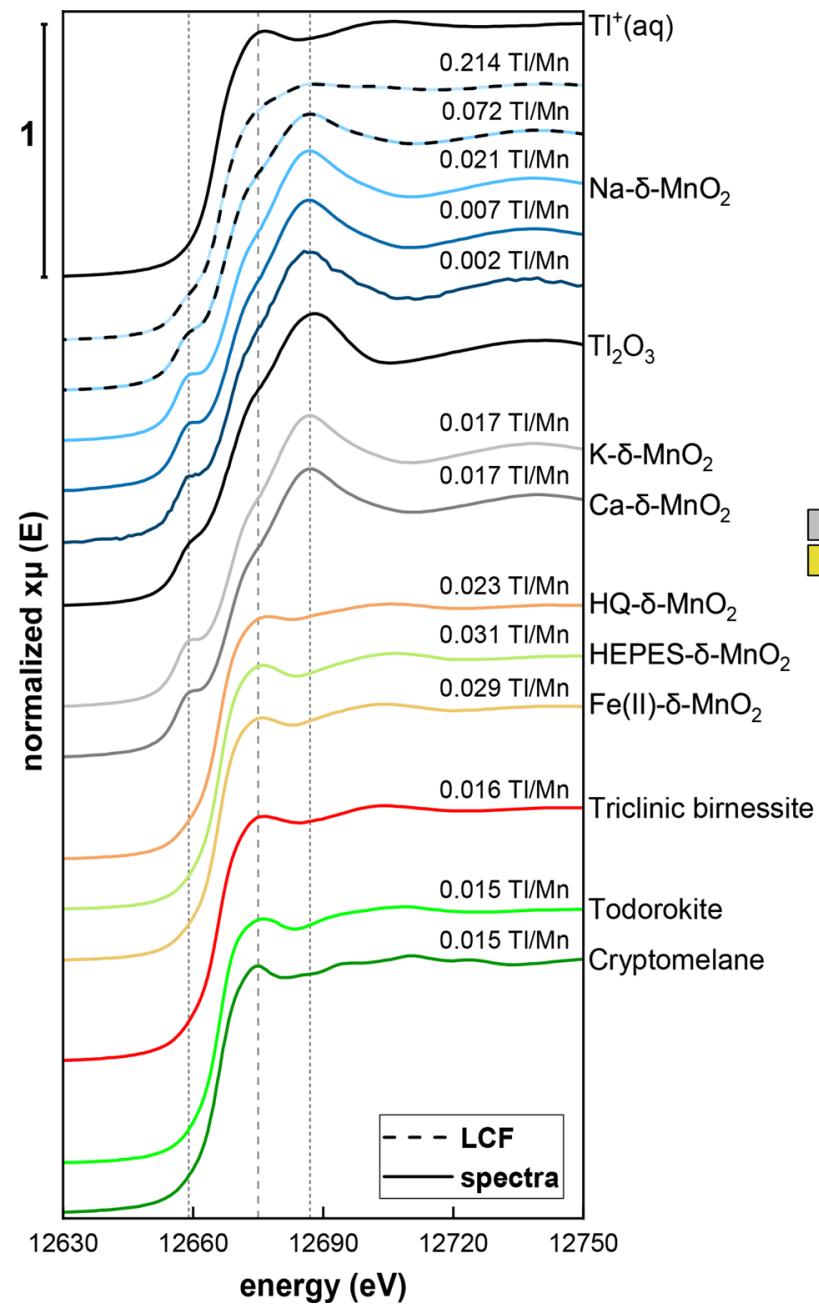

B

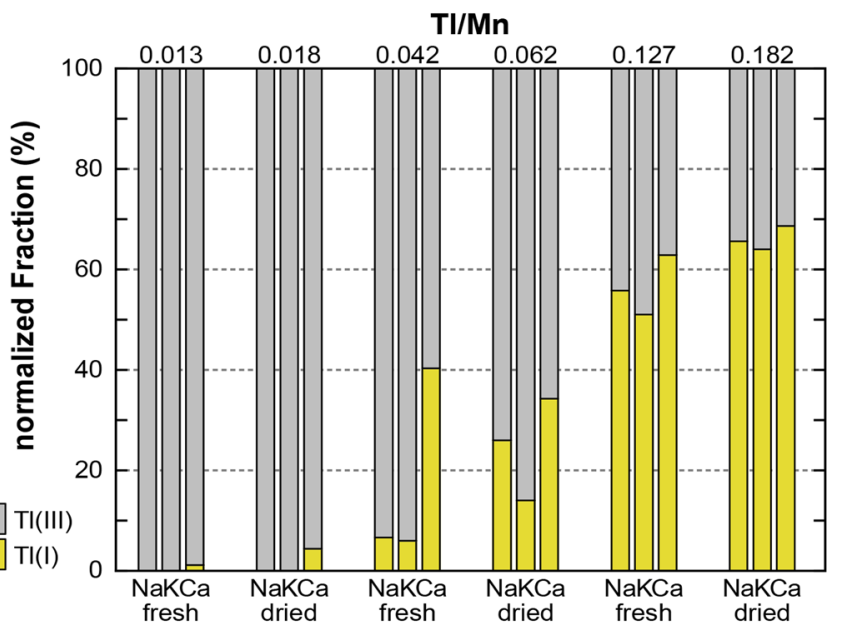

C

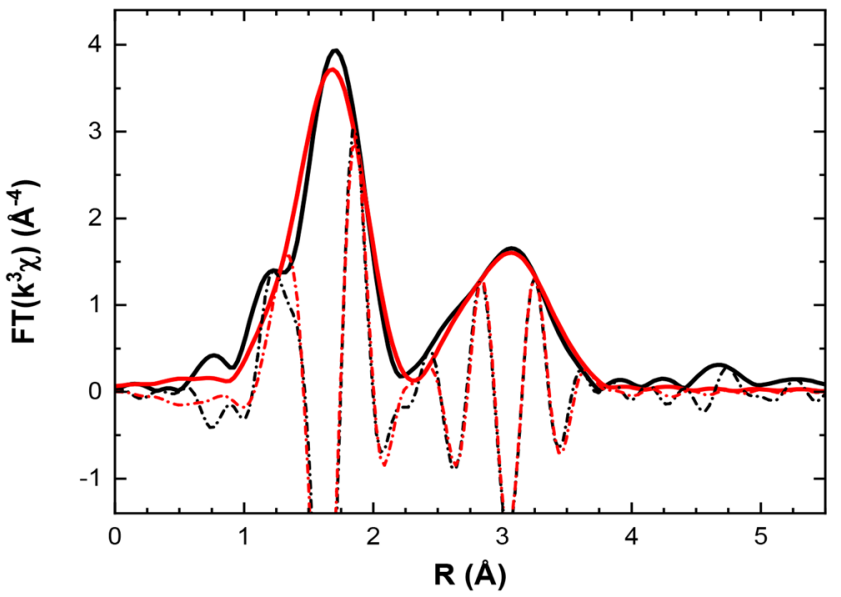

Figure 2. (A) $\mathrm{Tl} \mathrm{L}_{\mathrm{III}}$-edge XANES spectra of $\mathrm{Tl}$ sorbed onto Mn oxides (selected treatments). Spectra of $0.01 \mathrm{M} \mathrm{Tl}^{+}$dissolved in water $\left(\mathrm{Tl}^{+}{ }_{(\mathrm{aq})}\right.$ ) and $\mathrm{Tl}_{2} \mathrm{O}_{3}$ are shown as references for $\mathrm{Tl}(\mathrm{I})$ and $\mathrm{Tl}(\mathrm{III})$, respectively. For $\mathrm{Na}-\delta-\mathrm{MnO}_{2}$, spectra for all $\mathrm{Tl}$ loadings in molar $\mathrm{Tl} / \mathrm{Mn}$ are shown. For all other Mn oxides, only one spectrum (for loading of 0.015 to $0.031 \mathrm{Tl} / \mathrm{Mn}$ ) is shown. Vertical lines mark the pre-edge shoulder of $\mathrm{Tl}(\mathrm{III})\left(\mathrm{Tl} l_{2} \mathrm{O}_{3}\right.$; $12,659 \mathrm{eV})$ and the first maxima of the XANES of $\mathrm{Tl}(\mathrm{I})\left(\mathrm{Tl}^{+}{ }_{(\mathrm{aq})} ; 12,675 \mathrm{eV}\right)$ and $\mathrm{Tl}(\mathrm{III})\left(\mathrm{Tl}_{2} \mathrm{O}_{3} ; 12,687 \mathrm{eV}\right)$. (B) LCF-derived fractions of $\mathrm{Tl}(\mathrm{I})$ and $\mathrm{Tl}(\mathrm{III})$ for $\mathrm{Tl}$ sorbed onto fresh and dried Na-, K-, and $\mathrm{Ca}-\delta-\mathrm{MnO}_{2}$; grouped by averaged $\mathrm{Tl}$ loadings. (C) Fourier-transformed $k^{3}$-weighted $\mathrm{Tl}$ $\mathrm{L}_{\mathrm{III}}$-edge EXAFS spectrum of $\mathrm{Na}-\delta$ - $\mathrm{MnO}_{2}$ with a Tl(III) loading of $\sim 0.015 \mathrm{Tl} / \mathrm{Mn}$ recorded at $20 \mathrm{~K}$ (magnitude, solid black lines; imaginary part, dashed black lines) and corresponding shell fits (red lines). Additional spectra in Figures S9-S20; shell fit parameters in Table 3; shell fitting described in the Supporting Information.

exhibited a steep slope of $\sim 1.4$, indicating that $\mathrm{Tl}$ sorption affinity increased with $\mathrm{Tl}$ loading (Figure S7C).

TI $\mathrm{L}_{1 \mathrm{II}}$-Edge XANES Spectroscopy. In Figure 2A, selected XANES spectra of $\mathrm{Tl}$ sorbed onto different $\mathrm{Mn}$ oxides are shown, as well as the spectra of $\mathrm{Tl}_{2} \mathrm{O}_{3}$ and of $\mathrm{Tl}^{+}$dissolved in water $\left(\mathrm{Tl}^{+}{ }_{(\mathrm{aq})}\right)$ as independent reference spectra for $\mathrm{Tl}(\mathrm{III})$ and $\mathrm{Tl}(\mathrm{I})$, respectively (all XANES spectra are shown in Figures S9-S20).

The spectra of Tl sorbed onto (dried/resuspended) Na- $\delta$ $\mathrm{MnO}_{2}$ at loadings up to a molar $\mathrm{Tl} / \mathrm{Mn}$ ratio of $0.021(36,000$ $\mathrm{mg} / \mathrm{kg}$ ) closely match each other, and comparison to the reference spectra of $\mathrm{Tl}_{2} \mathrm{O}_{3}$ and $\mathrm{Tl}^{+}{ }_{(\text {aq) }}$ show that $\mathrm{Tl}$ was sorbed dominantly as $\mathrm{Tl}(\mathrm{III})$. Changes in the spectral features characteristic of $\mathrm{Tl}(\mathrm{III})$ and $\mathrm{Tl}(\mathrm{I})$ as loading increased from 0.021 to $0.21 \mathrm{Tl} / \mathrm{Mn}(36,000$ to $360,000 \mathrm{mg} / \mathrm{kg} \mathrm{Tl})$, on the other hand, pointed to an increasing fraction of sorbed $\mathrm{Tl}(\mathrm{I})$. This trend, which was also observed in the XANES data of all other $\delta$ - $\mathrm{MnO}_{2}$ batches, was quantified by LCF using the spectra of $\mathrm{Na}-\delta-\mathrm{MnO}_{2}$ with $0.021 \mathrm{Tl} / \mathrm{Mn}$ and triclinic birnessite with $0.054 \mathrm{Tl} / \mathrm{Mn}$ as proxies for $\mathrm{Tl}(\mathrm{III})$ and $\mathrm{Tl}(\mathrm{I})$, respectively. LCF-derived fractions of $\mathrm{Tl}(\mathrm{III})$ and $\mathrm{Tl}(\mathrm{I})$ are displayed in Figure 2B, and the reconstructed spectra for $\mathrm{Na}-\delta$ $\mathrm{MnO}_{2}$ are shown in Figure 2A (details in the Supporting Information, Section 3.2.2). No sorbed $\mathrm{Tl}(\mathrm{I})$ was detected on $\delta$ - $\mathrm{MnO}_{2}$ with up to $\sim 0.02 \mathrm{Tl} / \mathrm{Mn}(\sim 36,000 \mathrm{mg} / \mathrm{kg})$. At higher $\mathrm{Tl}$ loadings, the $\mathrm{Tl}(\mathrm{I})$ fraction increased to $\sim 61 \pm 6 \%$ on $\delta$ $\mathrm{MnO}_{2}$ with $\sim 0.2 \mathrm{Tl} / \mathrm{Mn}(\sim 360,000 \mathrm{mg} / \mathrm{kg})$.

The spectra of partially reduced $\delta-\mathrm{MnO}_{2}$, triclinic birnessite, todorokite, and cryptomelane with $0.015-0.031 \mathrm{Tl} / \mathrm{Mn}$ indicated that sorbed $\mathrm{Tl}$ was primarily $\mathrm{Tl}(\mathrm{I}$ ) (Figure $2 \mathrm{~A}$ and Figures S15-S20). For HEPES- $\delta-\mathrm{MnO}_{2}, \mathrm{Fe}(\mathrm{II})-\delta-\mathrm{MnO}_{2}$, triclinic birnessite, todorokite, and cryptomelane, XANES provided no indication for variations in the $\mathrm{Tl}$ oxidation state with loading (Figures S16-S20), indicating that Tl was bound as $\mathrm{Tl}(\mathrm{I})$ at all loadings. For $\mathrm{HQ}-\delta-\mathrm{MnO}_{2}$, on the other hand, minor spectral variations were observed with $\mathrm{Tl}$ loading, and LCF returned $\mathrm{Tl}(\mathrm{III})$ fractions between $12 \%$ (lowest loaded sample; $0.0023 \mathrm{Tl} / \mathrm{Mn} ; 3800 \mathrm{mg} / \mathrm{kg}$ ) and $3 \%$ (highest loaded sample; $0.20 \mathrm{Tl} / \mathrm{Mn} ; 343,000 \mathrm{mg} / \mathrm{kg}$ ) (Table S14 and Figure S15). 
Table 3. Structural Characterization of Tl(III) Bound to $\mathrm{Na}-\delta-\mathrm{MnO}_{2}$ and $\mathrm{K}-\boldsymbol{\delta}-\mathrm{MnO} \mathrm{O}_{2}$ by Simultaneous Shell Fit Analysis of EXAFS Spectra Obtained at $20 \mathrm{~K}$ or Room Temperature $(\mathrm{RT})^{a}$

\begin{tabular}{|c|c|c|c|c|c|c|}
\hline path & $R(\AA)^{b}$ & $\mathrm{CN}^{c}$ & $\sigma^{2}(20 \mathrm{~K})\left(\AA^{2}\right)^{d}$ & $\sigma^{2}(\mathrm{RT})\left(\AA^{2}\right)^{d}$ & $\Delta E_{0}(\mathrm{eV})$ & $r$-factor \\
\hline \multicolumn{7}{|c|}{$\mathrm{Na}-\delta-\mathrm{MnO}_{2}$ with $0.021 \mathrm{Tl} / \mathrm{Mn}$} \\
\hline $\mathrm{Tl}-\mathrm{O}$ & $2.20(0.01)$ & $5.6(0.3)$ & $0.011(0.001)$ & $0.013(0.001)$ & $-0.9(0.6)$ & 0.012 \\
\hline $\mathrm{Tl}-\mathrm{Mn} 1$ & $3.27(0.02)$ & $2.4(1.5)$ & $0.013(0.004)$ & $0.017(0.004)$ & & \\
\hline $\mathrm{Tl}-\mathrm{Mn} 2$ & $3.61(0.01)$ & $4.1(2.1)$ & 0.013 & 0.017 & & \\
\hline \multicolumn{7}{|c|}{$\mathrm{K}-\delta$ - $\mathrm{MnO}_{2}$ with $0.017 \mathrm{Tl} / \mathrm{Mn}$} \\
\hline $\mathrm{Tl}-\mathrm{O}$ & $2.20(0.01)$ & $5.7(0.3)$ & $0.011(0.001)$ & $0.013(0.001)$ & $-0.9(0.5)$ & 0.010 \\
\hline $\mathrm{Tl}-\mathrm{Mn} 1$ & $3.28(0.02)$ & $2.8(1.5)$ & $0.015(0.004)$ & $0.019(0.004)$ & & \\
\hline $\mathrm{Tl}-\mathrm{Mn} 2$ & $3.62(0.01)$ & $5.0(2.2)$ & 0.015 & 0.019 & & \\
\hline
\end{tabular}

${ }^{a}$ Additional fit information: EXAFS spectra over a $k$-range of 3-10 $\AA^{-1}$ Fourier-transformed (Kaiser-Bessel window, parameter $2 \AA^{-1}$ ). Simultaneous fitting at $k$-weights of 1,2 , and 3 over an $r$-range of $1.0-4.2 \AA$. Individual spectra of Tl(III)-sorbed $\mathrm{Na}-\delta$ - $\mathrm{MnO}_{2}$ and $\mathrm{K}$ - $\delta$-MnO recorded at $20 \mathrm{~K}$ and room temperature are shown in Figure S24 together with the modeled spectra. Values in parentheses correspond to statistical fit uncertainties derived from the Artemis software code ${ }^{37}$ but do not include systematic fit uncertainties. ${ }^{b}$ Interatomic distance (set to same values for spectra at RT and $20 \mathrm{~K}$ ). ${ }^{c}$ Coordination number $(\mathrm{CN})$ obtained with an amplitude reduction factor $\left(S_{0}{ }^{2}\right)$ of 0.96 (from fit of spectrum of $\mathrm{Tl}_{2} \mathrm{O}_{3}$; see Figure S23). ${ }^{d}$ Debye-Waller parameters (individual for spectra at $\mathrm{RT}$ and $20 \mathrm{~K} ; \sigma^{2}$ of $\mathrm{Tl}-\mathrm{Mn} 1$ and $\mathrm{Tl}-\mathrm{Mn} 2$ paths constrained to the same value).

TI L $L_{I I I}$-Edge EXAFS Spectroscopy. Tl sorbed onto Naand $\mathrm{K}-\delta-\mathrm{MnO}_{2}$ at loadings up to $\sim 0.02 \mathrm{Tl} / \mathrm{Mn}$ was $\mathrm{Tl}(\mathrm{III})$ based on XANES analysis (Figure 2A,B). The comparison of the XANES and EXAFS spectra of $\delta-\mathrm{MnO}_{2}$ with $\sim 0.0016$ and $\sim 0.0051 \mathrm{Tl} / \mathrm{Mn}$ with the spectrum of $\mathrm{Na}-\delta-\mathrm{MnO}_{2}$ with 0.021 $\mathrm{Tl} / \mathrm{Mn}$ suggested that the mode of $\mathrm{Tl}$ coordination did not change over this range in $\mathrm{Tl}$ loadings (Figure S25). The Fourier-transformed EXAFS spectra of $\sim 0.02 \mathrm{Tl}(\mathrm{III}) / \mathrm{Mn}$ sorbed onto Na- and $\mathrm{K}-\delta-\mathrm{MnO}_{2}$, recorded at room temperature and $20 \mathrm{~K}$, were evaluated by shell fitting to assess the coordination geometry of sorbed Tl(III) (Figure 2C, Table 3, and Supporting Information, Section 3.3.3). Nearly identical fit results were obtained for $\mathrm{Na}$ - and $\mathrm{K}-\delta-\mathrm{MnO}_{2}$, as expected from the similar EXAFS spectra.

The rather high Debye-Waller factors of the first-shell Tl$\mathrm{O}$ and the second-shell $\mathrm{Tl}-\mathrm{Mn}$ paths point to substantial structural disorder. This disorder most probably originates from variations in the distribution of $\mathrm{Mn}$ (III) and $\mathrm{Mn}$ (IV) around individual sorption sites and related gradual variations in sorption site geometry. ${ }^{62}$ Because of the high structural disorder, fitted coordination numbers should be interpreted with caution. The fitted average $\mathrm{Tl}-\mathrm{O}$ and $\mathrm{Tl}-\mathrm{Mn}$ distances, however, seem reliable, as they allowed describing spectra recorded at room temperature as well as $20 \mathrm{~K}$ (Figure S24). ${ }^{62}$

Shell fitting returned a first-shell Tl-O distance of $2.20 \AA$ and coordination number of $\sim 5.6-5.7$. The Tl-O distance is in good agreement with reported average first-shell distances for $\mathrm{Tl}(\mathrm{III})$ sorbed onto hexagonal birnessite and $\delta-\mathrm{MnO}_{2}{ }^{11,23}$ The fitted coordination number, on the other hand, is higher than reported previously ${ }^{11}$ and points to six-fold (octahedral) rather than four-fold (tetrahedral) coordination of $\mathrm{Tl}$ (III) with O. The fitted Tl-O distance of $2.20 \AA$ is shorter than the crystallographic Tl-O distance of six-fold O-coordinated $\mathrm{Tl}(\mathrm{III})$ in $\mathrm{Tl}_{2} \mathrm{O}_{3}(2.27 \AA),{ }^{63}$ but matches the EXAFS-derived Tl-O distance of six-fold water-coordinated aqueous $\mathrm{Tl}^{3+}$ $(2.20-2.21 \AA),{ }^{64}$ and is thus compatible with octahedral $\mathrm{Tl}(\mathrm{III})$ coordination.

To describe the second-shell peak, contributions from $\mathrm{Mn}$ at distances of 3.61-3.62 and 3.27-3.28 $\AA$ had to be included in the fit (Table 3 ). The longer $\mathrm{Tl}-\mathrm{Mn}$ distance has previously been reported for $\mathrm{Tl}$ sorbed onto crystalline hexagonal birnessite (AMON 3.72; Tl/Mn $\sim 0.001)^{11}$ and $\delta-\mathrm{MnO}_{2}$ (AMON 4.0; Tl/Mn $\geq 0.08)^{23}$ and was attributed to binding of $\mathrm{Tl}(\mathrm{III})$ on top of vacancy sites in a triple corner-sharing configuration. $^{11,23}$ The second shorter $\mathrm{Tl}-\mathrm{Mn}$ distance has previously been reported for $\mathrm{Tl}$ sorbed onto $\delta-\mathrm{MnO}_{2}$ and was tentatively attributed to (double edge-sharing) binding of $\mathrm{Tl}(\mathrm{III})$ at the lateral edges of $\delta-\mathrm{MnO}_{2}$ platelets. ${ }^{23}$ This interpretation was based on the consideration that $\delta-\mathrm{MnO}_{2}$ particles carry a higher fraction of edge sites than larger and more crystalline particles of hexagonal birnessite and on earlier results on the coordination of lead $(\mathrm{Pb})$ on $\delta-\mathrm{MnO}_{2}{ }^{23,65}$ Alternatively, the differences in $\mathrm{Tl}(\mathrm{III})$ coordination could be linked to differences in the AMON and related variations in the structure of layered $\mathrm{Mn}$ oxides. Further work will be needed to unravel the modes of $\mathrm{Tl}$ (III) coordination on vacancy-containing layered $\mathrm{Mn}$ oxides and controlling factors.

The XANES spectra of $\mathrm{Tl}(\mathrm{I})$ sorbed onto triclinic birnessite and todorokite resembled the spectrum of aqueous $\mathrm{Tl}^{+}$(Figure $2 \mathrm{~A})$, and the corresponding EXAFS spectra showed very low first-shell amplitudes similar to dissolved $\mathrm{Tl}^{+}$(Figure S21). These spectral similarities indicate that $\mathrm{Tl}^{+}$in the interlayers of triclinic birnessite and in the tunnels of todorokite exhibits a disordered first-shell Tl-O similar to hydrated $\mathrm{Tl}^{+}$, most probably because sorbed $\mathrm{Tl}^{+}$remains (largely) hydrated. The same applies for the partially reduced $\delta$ - $\mathrm{MnO}_{2}$ for which similar EXAFS spectra as for triclinic birnessite and todorokite were observed (not shown). In contrast, marked oscillations were visible in the XANES (Figure 2A) and EXAFS (Figure $\mathrm{S} 21$ ) of $\mathrm{Tl}(\mathrm{I})$ sorbed onto cryptomelane, indicative for a more ordered local $\mathrm{Tl}$ coordination, most probably due to the replacement of structural $\mathrm{K}^{+}$by fully dehydrated $\mathrm{Tl}^{+}$. This interpretation was supported by shell fitting, which showed that the EXAFS signal of $\mathrm{Tl}(\mathrm{I})$ sorbed onto cryptomelane was reasonably reproduced with a model assuming $\mathrm{Tl}^{+}$to be located on the position of $\mathrm{K}^{+}$in the cryptomelane structure (Figure S26).

\section{DISCUSSION}

High-Affinity Oxidative TI Sorption onto VacancyContaining $\delta-\mathrm{MnO}_{2}$. The low slope of the $\mathrm{Tl}$ sorption isotherm on $\delta-\mathrm{MnO}_{2}$ and the very high sorption affinity at low $\mathrm{Tl}$ concentrations point to a distinct high-affinity uptake mechanism. XAS results confirm that $\mathrm{Tl}$ uptake up to loadings of $\sim 0.02 \mathrm{Tl} / \mathrm{Mn}(\sim 36,000 \mathrm{mg} / \mathrm{kg})$ occurs mainly via an oxidation-complexation mechanism. At $\mathrm{Tl} / \mathrm{Mn}$ loadings 
above $\sim 0.02$, increasing fractions of $\mathrm{Tl}$ are sorbed as $\mathrm{Tl}(\mathrm{I})$, most probably in the hydrated form since the $\mathrm{Tl}(\mathrm{I})$ fraction could be adequately described by the spectrum of $\mathrm{Tl}(\mathrm{I})$ sorbed onto triclinic birnessite in the LCF analysis (Fig. 2AB). In parallel, at total loadings up to $\sim 0.2 \mathrm{Tl} / \mathrm{Mn}$, the $\mathrm{Tl}$ (III) loading leveled out at $0.06 \pm 0.01 \mathrm{Tl}(\mathrm{III}) / \mathrm{Mn}$ (Figures $1 \mathrm{~F}$ and $2 \mathrm{~B}$ ). Since the oxidative uptake of $\mathrm{Tl}$ results in the transfer of two electrons to $\mathrm{Mn}$, a maximum loading of $0.06 \mathrm{Tl}(\mathrm{III}) / \mathrm{Mn}$ corresponds to the reduction of $0.12 \mathrm{Mn}(\mathrm{IV}) / \mathrm{Mn}_{\text {tot }}$ to $\mathrm{Mn}$ (III) (or $0.06 \mathrm{Mn}(\mathrm{IV}) / \mathrm{Mn}_{\text {tot }}$ to $\mathrm{Mn}(\mathrm{II})$ ), equivalent to a decrease in AMON from 4.0 to 3.88 if no $\mathrm{Mn}^{2+}$ is released into solution. ${ }^{23}$ Considering common vacancy contents of $\delta-\mathrm{MnO}_{2}$ of $0.06-0.11$ per $\mathrm{Mn},{ }^{21,36,66,67}$ the limitation of oxidative $\mathrm{Tl}$ uptake may be linked to the blocking of vacancy sites by $\mathrm{Tl}(\mathrm{III})$ and $\mathrm{Mn}$ (III). However, the two $\mathrm{Tl}(\mathrm{III})-\mathrm{Mn}$ distances observed by EXAFS spectroscopy, which may result from $\mathrm{Tl}$ (III) coordination on different sites (e.g., vacancy and edge sites), point to a more complex mechanism. More generally, the limitation in oxidative $\mathrm{Tl}$ uptake may be related to increasing $\mathrm{Mn}$ reduction and related decreases in the redox reactivity of $\delta-\mathrm{MnO}_{2}$ and in the thermodynamic driving force for further Tl oxidation. Analogously, decreases in the rates of bisphenol $\mathrm{A}$ and arsenite oxidation by $\delta-\mathrm{MnO}_{2}$ over time have been attributed to the accumulation of $\mathrm{Mn}$ (III) and $\mathrm{Mn}$ (II) in the solid phase. ${ }^{24,30,31}$

Thermodynamic calculations suggest that dissolved $\mathrm{Tl}$ in the sorption experiments is $\mathrm{Tl}(\mathrm{I})$, mostly as free hydrated $\mathrm{Tl}^{+}$, as confirmed analytically for two suspensions of $\delta-\mathrm{MnO}_{2}$ with $\sim 0.017 \mathrm{Tl} / \mathrm{Mn}$ (Supporting Information, Section 2.6). Assuming that sorbed $\mathrm{Tl}(\mathrm{III})$ is insoluble relative to sorbed $\mathrm{Tl}(\mathrm{I})$ and that $\mathrm{Tl}(\mathrm{I})$ sorbs onto $\delta-\mathrm{MnO}_{2}$ with similar sorption affinity as onto triclinic birnessite, one can estimate from the $K_{\mathrm{d}}$ values in Table 2 that, at a dissolved Tl concentration of $10^{-8} \mathrm{M}$, corresponding to a $\mathrm{Tl}$ loading of $\delta-\mathrm{MnO}_{2}$ of $\sim 0.03$ $\mathrm{Tl} / \mathrm{Mn}(\sim 50,000 \mathrm{mg} / \mathrm{kg})$, only $\sim 1 \%$ of the total solid-phase $\mathrm{Tl}$ is $\mathrm{Tl}(\mathrm{I})$. Analogously, for a dissolved $\mathrm{Tl}$ concentration of $10^{-11}$ $\mathrm{M}$, corresponding to a $\mathrm{Tl}$ loading of $\sim 0.006 \mathrm{Tl} / \mathrm{Mn}(\sim 10,000$ $\mathrm{mg} / \mathrm{kg}$ ), sorbed $\mathrm{Tl}(\mathrm{I})$ would account for less than $0.1 \%$ of sorbed Tl. The flat slope of the Tl sorption isotherm for $\delta$ $\mathrm{MnO}_{2}$ in the lower concentration range thus most probably reflects that variations in dissolved $\mathrm{Tl}$ over several orders of magnitude are linked to variations in the very small fraction of sorbed $\mathrm{Tl}(\mathrm{I})$ that are not analytically accessible. Assuming that initial oxidative Tl uptake onto $\delta-\mathrm{MnO}_{2}$ at low Tl loadings occurs within hours, dissolved $\mathrm{Tl}(\mathrm{I})$ concentrations might decrease over time due to continuing slow oxidation of residual sorbed $\mathrm{Tl}(\mathrm{I})$, without marked changes in total sorbed $\mathrm{Tl}$, as observed for cobalt. ${ }^{37}$ Thus, as we determined sorption isotherms after an equilibration time of $\sim 24 \mathrm{~h}$, somewhat higher $\log K_{\mathrm{d}}$ values for oxidative $\mathrm{Tl}$ uptake onto $\delta-\mathrm{MnO}_{2}$ might apply over longer equilibration times.

Published sorption data for $\mathrm{Tl}$ uptake by $\delta-\mathrm{MnO}_{2}$ roughly fall onto the sorption isotherm for $\delta$ - $\mathrm{MnO}_{2}$ measured in the present study (Figure 1E). Earlier sorption studies were mostly conducted at very high dissolved $\mathrm{Tl}$ concentrations at which $\mathrm{Tl}$ is sorbed both oxidatively and nonoxidatively. The variation in sorbed amounts over about one order of magnitude for a given dissolved $\mathrm{Tl}$ concentration may arise from differences in the reactivity of the vacancy-containing $\mathrm{Mn}$ oxides, solution $\mathrm{pH}$, or other experimental factors that varied among the different studies. The few published data for $\mathrm{Tl}$ sorption onto hexagonal birnessite at low $\mathrm{Tl}$ loadings ${ }^{3}$ fall close to our sorption isotherm for $\delta-\mathrm{MnO}_{2}$, suggesting that this sorption isotherm adequately represents the affinity of oxidative $\mathrm{Tl}$ sorption onto vacancy-containing hexagonal phyllomanganates.

Effect of Partial $\delta$ - $\mathrm{MnO}_{2}$ Reduction on TI Sorption. In natural systems, freshly formed biogenic Mn oxides (or $\delta$ $\mathrm{MnO}_{2}$ ) may undergo phase changes induced by the reaction with reductants such as organic compounds or dissolved $\mathrm{Fe}$ (II) or $\mathrm{Mn}(\mathrm{II})$. At near-neutral $\mathrm{pH}$, partial $\delta-\mathrm{MnO}_{2}$ reduction may increase the $\mathrm{Mn}(\mathrm{III})$ content of $\delta-\mathrm{MnO}_{2}$ and decrease its reactivity, among other factors through the blocking of vacancy sites by interlayer $\mathrm{Mn}(\mathrm{III}) .^{24-27,53}$ The HQ- and HEPESreacted $\delta-\mathrm{MnO}_{2}$ corresponded to $\mathrm{Mn}(\mathrm{III})$-rich $\delta-\mathrm{MnO}_{2}$, and the respective sorption isotherms confirmed that $\mathrm{Tl}$ sorption was lower than on unreacted $\delta-\mathrm{MnO}_{2}$ (Figure 1B). Less Tl was sorbed onto HEPES- $\delta$ - $\mathrm{MnO}_{2}$ than $\mathrm{HQ}-\delta$ - $\mathrm{MnO}_{2}$, which may be due to the lower $\mathrm{pH}$ in the adsorption experiment with HEPES- $\delta$ - $\mathrm{MnO}_{2}$ (Table 2) or due to the lower AMON of HEPES- $\delta-\mathrm{MnO}_{2}$ (Table 1 ). The XANES data revealed that the reductive transformation of $\delta$ - $\mathrm{Mn}(\mathrm{IV}) \mathrm{O}_{2}$ into $\mathrm{Mn}(\mathrm{III})$-rich $\delta$ $\mathrm{MnO}_{2}$ effectively inhibited oxidative $\mathrm{Tl}$ uptake and promoted the binding of hydrated $\mathrm{Tl}^{+}$(Figure 2A). Interestingly, XANES analysis showed that some $\mathrm{Tl}$ oxidation still occurred on HQ$\delta-\mathrm{MnO}_{2}$. In combination with the slightly higher AMON and the slightly higher sorption affinity of $\mathrm{HQ}-\delta-\mathrm{MnO}_{2}$ relative to HEPES- $\delta$ - $\mathrm{MnO}_{2}$ (Table 1 and Figure 1B), this finding supports the notion that oxidative $\mathrm{Tl}$ uptake by $\delta-\mathrm{MnO}_{2}$ is constrained by the availability of unblocked vacancy sites. The sorption isotherms of $\mathrm{HQ}-\delta-\mathrm{MnO}_{2}$ and HEPES- $\delta-\mathrm{MnO}_{2}$ exhibited a lower slope than the isotherm of triclinic birnessite. This could reflect a larger variety in sorption sites, possibly related to interlayer $\mathrm{Mn}(\mathrm{III})$ in $\mathrm{HQ}-\delta-\mathrm{MnO}_{2}$ and HEPES- $\delta$ $\mathrm{MnO}_{2}$. For $\mathrm{Cs}^{+}$, which was shown by XAS to sorb as hydrated cation onto triclinic and biogenic birnessite, more specific interactions were observed with biogenic $\mathrm{Mn}$ oxide with interlayer $\mathrm{Mn}(\mathrm{III})$ than with triclinic birnessite with layer $\mathrm{Mn}$ (III). ${ }^{68,69}$

The reaction of $\delta$ - $\mathrm{MnO}_{2}$ with $\mathrm{Fe}(\mathrm{II})$ at acidic $\mathrm{pH}$ caused its (at least partial) transformation into nsutite, a tectomanganate, and resulted in a $\mathrm{Mn}$ oxide with an AMON of 23.9 . Like the $\mathrm{Mn}(\mathrm{III})$-rich $\delta$ - $\mathrm{MnO}_{2}$ (HQ- $\delta$ - $\mathrm{MnO}_{2}$ and HEPES- $\delta$ - $\mathrm{MnO}_{2}$ ), $\mathrm{Fe}(\mathrm{II})-\delta-\mathrm{MnO}_{2}$ exhibited a substantially lower $\mathrm{Tl}$ sorption affinity and capacity than the unreacted $\delta-\mathrm{MnO}_{2}$ (Figure $1 \mathrm{~B}$ and Table 2), and XANES analysis showed that $\mathrm{Tl}$ was exclusively sorbed as $\mathrm{Tl}(\mathrm{I})$ (Figure $2 \mathrm{~A}$ ). Taken together, the experiments with partially reduced $\delta-\mathrm{MnO}_{2}$ thus demonstrate that the reductive transformation of $\delta$ - $\mathrm{Mn}(\mathrm{IV}) \mathrm{O}_{2}$ may lead to the formation of a $\mathrm{Mn}(\mathrm{III})$-rich $\delta-\mathrm{MnO}_{2}$ or a tectomanganate, depending on $\mathrm{pH}$, and that both types of transformation products bind $\mathrm{Tl}(\mathrm{I})$ nonoxidatively and with lower sorption affinity than $\delta$ - $\mathrm{Mn}(\mathrm{IV}) \mathrm{O}_{2}$.

Nonoxidative TI Sorption onto Vacancy-Free Triclinic Birnessite. Triclinic birnessite may form as a consequence of the reductive transformation of $\delta$ - $\mathrm{MnO}_{2} \cdot{ }^{38}$ The sorption isotherm of $\mathrm{Tl}$ on triclinic birnessite exhibits a slope of $\sim 0.8$ (Table 2), indicative of one major type of sorption site with limited variations in sorption affinity as a function of $\mathrm{Tl}$ loading. This interpretation is supported by the XAS data, which suggest that sorbed $\mathrm{Tl}(\mathrm{I})$ remained hydrated at all loadings. Together, these findings suggest that $\mathrm{Tl}(\mathrm{I})$ was mostly sorbed as outer-sphere complex by cation exchange similar to the sorption of $\mathrm{Cs}^{+}$onto triclinic birnessite. Data on $\mathrm{Cs}^{+}$sorption show a strong sorption competition with major cations such as $\mathrm{Na}^{+}, \mathrm{K}^{+}, 71,72$ and $\mathrm{Ca}^{2+68}$ and the same is probably true for the sorption of $\mathrm{Tl}^{+}$onto triclinic birnessite. 
Together with the results obtained for $\delta$ - $\mathrm{MnO}_{2}$ and partially reduced $\delta-\mathrm{MnO}_{2}$, the results on $\mathrm{Tl}$ sorption onto triclinic birnessite clearly support the conclusion that oxidative $\mathrm{Tl}$ uptake is limited to phyllomanganates containing free (uncapped) vacancies in their octahedral layers.

Sorption of Tl onto the Tectomanganates Todorokite and Cryptomelane. Similar to the results obtained for triclinic birnessite and the partially reduced $\delta-\mathrm{MnO}_{2}, \mathrm{XAS}$ suggested that $\mathrm{Tl}(\mathrm{I})$ was sorbed onto todorokite mostly as hydrated cation (Figure 2A and Figure S19), in line with an earlier study ${ }^{11}$ and in analogy to $\mathrm{Cs}^{+}{ }^{+9,68}$ Solution data indicated that $\mathrm{Mg}$ release was relatively close to stoichiometric exchange (Supporting Information, Section 2.4), supporting the notion that sorption was dominated by the cation exchange. The relatively low slope of the sorption isotherm for $\mathrm{Tl}^{+}$uptake by todorokite may result from $\mathrm{Tl}^{+}$sorption via cation exchange on multiple sites, as proposed for $\mathrm{Cs}^{+} .68$

The sorption isotherm of $\mathrm{Tl}$ on cryptomelane indicated an increase in $\mathrm{Tl}$ sorption affinity with loading. The highest $\mathrm{Tl}$ loading of $0.048 \mathrm{Tl} / \mathrm{Mn}$ corresponded to about $30 \%$ of the initial structural $\mathrm{K}$ (Table 1) and was relatively closely matched by a corresponding release of $\mathrm{K}^{+}$into solution (Supporting Information, Section 2.4). XAS indicated that dehydrated $\mathrm{Tl}^{+}$ replaced $\mathrm{K}^{+}$in the cryptomelane tunnels. The increase in $\mathrm{Tl}$ sorption affinity with $\mathrm{Tl}$ loading most probably reflects a transition from K-cryptomelane toward a more stable $\mathrm{Tl}$ substituted cryptomelane. In line with our findings for $\mathrm{Tl}^{+}$, it has been shown that $\mathrm{Rb}^{+}$with a similar ionic radius and hydration energy as $\mathrm{Tl}^{+14}$ strongly binds in the $2 \times 2$ tunnels of cryptomelane. ${ }^{73,74}$

Environmental Implications. In Figure 1E, the sorption isotherms for $\delta-\mathrm{MnO}_{2}$ and triclinic birnessite are compared to literature data on $\mathrm{Tl}(\mathrm{I})$ sorption onto other sorbents in terrestrial and aquatic systems: humic acids, ${ }^{75}$ ferrihydrite, ${ }^{76}$ and illite. ${ }^{14}$ The comparison highlights the exceedingly high selectivity of oxidative $\mathrm{Tl}$ uptake by $\delta-\mathrm{MnO}_{2}$ at low dissolved $\mathrm{Tl}(\mathrm{I})$ concentrations and that vacancy-containing $\mathrm{Mn}$ oxides may retain substantial amounts of Tl. Although $\delta-\mathrm{MnO}_{2}$ (and biogenic $\mathrm{Mn}$ oxides) may transform into less reactive $\mathrm{Mn}$ oxides such as $\mathrm{Mn}(\mathrm{III})$-rich $\delta$ - $\mathrm{MnO}_{2}$, triclinic birnessite, or tectomanganates $^{28,38,61,77}$ that bind $\mathrm{Tl}(\mathrm{I})$ nonoxidatively, these $\mathrm{Mn}$ oxides still exhibit higher sorption affinities and capacities for $\mathrm{Tl}(\mathrm{I})$ relative to other potential sorbents. However, the often low abundance of $\mathrm{Mn}$ oxides relative to other sorbent phases and their instability under reducing conditions may be factors that limit their importance for $\mathrm{Tl}$ sequestration under certain conditions. Furthermore, sorption competition with other cations must be taken into account. We hypothesize that sorption competition of $\mathrm{Tl}$ with other trace metals including $\mathrm{Mn}$ (III) is especially relevant for sorption onto vacancycontaining phyllomanganates that bind a wide range of trace elements with high affinity, ${ }^{34,36,37,62,65,78}$ whereas competition with major cations is probably especially relevant for triclinic birnessite onto which $\mathrm{Tl}(\mathrm{I})$ sorbs less specifically.

At a very high dissolved $\mathrm{Tl}(\mathrm{I})$ concentration of $10^{-5} \mathrm{M}$, as might occur in heavily $\mathrm{Tl}$ polluted wastewaters, ${ }^{4}$ the sorption capacity of most Mn oxides is approached and the (still high) $K_{\mathrm{d}}$ values of the tested $\mathrm{Mn}$ oxides vary by only about one order of magnitude (Table 1A-C, Figure S7, and Table 2). This suggests that phyllomanganates as well as tectomanganates could be suitable sorbents for $\mathrm{Tl}$ removal from heavily contaminated waters.
For the mean $\mathrm{Tl}$ concentration of seawater of $6.5 \times 10^{-11}$ $\mathrm{M}^{13}$ a $\log K_{\mathrm{d}}$ of 9.1 for oxidative Tl sorption onto $\delta-\mathrm{MnO}_{2}$ and of 6.0 for nonoxidative $\mathrm{Tl}$ sorption onto triclinic birnessite can be estimated from our results (Table 2), corresponding to loadings of $\sim 16,000 \mathrm{mg} / \mathrm{kg} \mathrm{Tl}$ on $\delta-\mathrm{MnO}_{2}$ and of $\sim 13 \mathrm{mg} / \mathrm{kg}$ $\mathrm{Tl}$ on triclinic birnessite (ignoring competitive sorption). For todorokite, a common mineral in marine $\mathrm{Mn}$ nodules, ${ }^{11}$ a similar loading as for triclinic birnessite may be assumed, based on sorption data for $\mathrm{Cs}^{+}$at similar concentrations. ${ }^{68}$ These estimates suggest that $\mathrm{Tl}$ contents of $100 \mathrm{mg} / \mathrm{kg}$ or more in marine ferromanganese nodules and crusts ${ }^{4,79,80}$ may either result from oxidative accumulation of $\mathrm{Tl}$ from seawater on vacancy-containing birnessite or from nonoxidative sorption of $\mathrm{Tl}(\mathrm{I})$ on other Mn oxides from $\mathrm{Tl}(\mathrm{I})$-enriched hydrothermal fluids, processes that can be differentiated based on their effect on stable $\mathrm{Tl}$ isotope fractionation. ${ }^{3,80}$

For a dissolved $\mathrm{Tl}(\mathrm{I})$ concentration of $10^{-8} \mathrm{M}$, the US EPA drinking water limit $(2 \mu \mathrm{g} / \mathrm{L}),{ }^{5} \log K_{\mathrm{d}}$ values of 7.4 and $5.5 \mathrm{can}$ be estimated for $\delta$ - $\mathrm{MnO}_{2}$ and triclinic birnessite (Table 2), corresponding to $\mathrm{Tl}$ loadings of $\sim 50,000$ and $\sim 650 \mathrm{mg} / \mathrm{kg}$, respectively. Fully oxidized $\delta$ - $\mathrm{Mn}(\mathrm{IV}) \mathrm{O}_{2}$ is thus a much more effective sorbent for $\mathrm{Tl}$ removal from drinking water than triclinic birnessite and sorbs also more $\mathrm{Tl}$ than partially reduced $\delta-\mathrm{MnO}_{2}$ or todorokite and cryptomelane. Notably, in equilibrium with $10^{-8} \mathrm{M} \mathrm{Tl}(\mathrm{I})$, the capacity of $\delta-\mathrm{MnO}_{2}$ for oxidative $\mathrm{Tl}$ sorption may already be reached and nonoxidative $\mathrm{Tl}(\mathrm{I})$ sorption may be relevant as well.

We previously determined a $\log K_{\mathrm{d}}$ of 3.4 for $\mathrm{Tl}(\mathrm{I})$ sorption onto illite in soil pore water at $10^{-8} \mathrm{M} \mathrm{Tl}(\mathrm{I})$, corresponding to $\sim 5 \mathrm{mg} / \mathrm{kg}$ sorbed $\mathrm{Tl}$. The four $\left(\delta-\mathrm{MnO}_{2}\right)$ to two orders of magnitude (triclinic birnessite and cryptomelane) higher loadings of $\mathrm{Mn}$ oxides at the same $\mathrm{Tl}(\mathrm{I})$ concentration show that even low amounts of $\mathrm{Mn}$ oxides may impact on the solubility and bioavailability of $\mathrm{Tl}$ in soils. However, as stated above, factors such as sorbent abundance, sorption competition, and (reduction-induced) transformation or dissolution of $\mathrm{Mn}$ oxides must be considered as well when assessing the relevance of $\mathrm{Mn}$ oxides for $\mathrm{Tl}$ retention in soils and sediments.

This study offers new insights into the extents and mechanisms of $\mathrm{Tl}$ sorption onto environmentally relevant Mn oxides. It thus supports the assessment of the relevance of different $\mathrm{Mn}$ oxides for environmental $\mathrm{Tl}$ cycling and for $\mathrm{Tl}$ removal in water treatment in comparison to other sorbents and processes. Important topics for continuing research on the interactions of $\mathrm{Tl}$ with $\mathrm{Mn}$ oxides include the effects of competitively sorbing major and trace element cations on $\mathrm{Tl}$ binding, the sorption of $\mathrm{Tl}$ onto biogenic $\mathrm{Mn}$ oxides, the reversibility of oxidative and nonoxidative $\mathrm{Tl}$ sorption onto different $\mathrm{Mn}$ oxides, or the potential release of $\mathrm{Tl}$ from $\mathrm{Mn}$ oxides under reducing conditions.

\section{ASSOCIATED CONTENT}

\section{Supporting Information}

The Supporting Information is available free of charge on the ACS Publications website at DOI: 10.1021/acs.est.9b04454.

Details on the synthesis of Mn oxides; XRD data; STEM images of $\delta-\mathrm{MnO}_{2}$, triclinic birnessite, and cryptomelane; details on AMON titration and stoichiometry calculations; review of literature data for $\mathrm{N}_{2}$-BET, $\mathrm{AMON}$, and cation/Mn molar ratios of $\mathrm{Mn}$ oxides; timeline of the experiments; details on sorption experiments; tabulated sorption data; final dissolved 
concentrations of $\mathrm{Mg}$ (todorokite) and $\mathrm{K}$ (cryptomelane) after sorption; complementary plots of sorption isotherms; calculation and analysis of dissolved $\mathrm{Tl}$ redox speciation in sorption experiments; derivation of literature sorption data; details on XAS data collection and extraction; complete set of XANES spectra and tabulated LCF fits; EXAFS spectra of references and selected samples and details of shell fits of spectra of $\mathrm{Tl}_{2} \mathrm{O}_{3} ; \mathrm{Tl}(\mathrm{III})$ sorbed onto $\delta$ - $\mathrm{MnO}_{2}$ and $\mathrm{Tl}(\mathrm{I})$ sorbed onto cryptomelane; comparison of XANES and EXAFS spectra of $\delta-\mathrm{MnO}_{2}$ with $\sim 0.0016, \sim 0.0051$, and 0.021 sorbed $\mathrm{Tl}(\mathrm{III}) / \mathrm{Mn}$ (PDF)

\section{AUTHOR INFORMATION}

\section{Corresponding Author}

*E-mail: andreas.voegelin@eawag.ch. Phone: +41 5876554 70. Fax: +4158765 5802 .

\section{ORCID}

Jasquelin Peña: 0000-0001-7081-3873

Andreas Voegelin: 0000-0003-2873-8966

\section{Notes}

The authors declare no competing financial interest.

\section{ACKNOWLEDGMENTS}

We thank Numa Pfenninger, Brian Sinnet, and Irene Brunner (Eawag) and Micaela Faria (University of Lausanne) for laboratory support, Ralf Kägi (Eawag) for STEM analyses, Frank Winnefeld (Swiss Federal Laboratories for Materials Science and Technology, Empa) for XRD data collection, Julie Tolu (Eawag) for HPLC-ICP-MS support, and Francesco Marafatto (Eawag) and Bernhard Wehrli (Eawag, ETH Zurich) for stimulating discussions. The Swiss-Norwegian Beamline (SNBL) and the Dutch-Belgian Beamline (DUBBLE) at the European Synchrotron Radiation Facility (ESRF, Grenoble, France) are acknowledged for beamtime at their EXAFS endstations, the synchrotron light source Soleil (Gifsur-Yvette, France) for beamtime at the beamline SAMBA (Spectroscopy Applied to Material Based on Absorption), and the Swiss Light Source (SLS, Villigen-PSI, Switzerland) for beamtime at the SuperXAS beamline. Hermann Emerich (SNBL), Dipanjan Banerjee (DUBBLE), Gautier Landrot (SAMBA), and Olga Safonova (SuperXAS) are thanked for their support during XAS data collection. This work was financially supported by the Swiss National Science Foundation (contract no. 200021-162364).

\section{REFERENCES}

(1) Kabata-Pendias, A. Trace Elements in Soils and Plants; 4th Ed.; CRC Press: Boca Raton, 2011.

(2) Kersten, M.; Xiao, T.; Kreissig, K.; Brett, A.; Coles, B. J.; Rehkämper, M. Tracing anthropogenic thallium in soil using stable isotope compositions. Environ. Sci. Technol. 2014, 48, 9030-9036.

(3) Nielsen, S. G.; Wasylenki, L. E.; Rehkämper, M.; Peacock, C. L.; Xue, Z.; Moon, E. M. Towards an understanding of thallium isotope fractionation during adsorption to manganese oxides. Geochim. Cosmochim. Acta 2013, 117, 252-265.

(4) Nriagu, J. O. Thallium in the Environment; John Wiley and Sons: New York, Chichester, Weinheim, Brisbane, Singapore, Toronto, 1998, p 284

(5) Peter, A. L. J.; Viraraghavan, T. Thallium: a review of public health and environmental concerns. Environ. Int. 2005, 31, 493-501.
(6) Tremel, A.; Masson, P.; Sterckeman, T.; Baize, D.; Mench, M. Thallium in French agrosystems I. Thallium contents in arable soils. Environ. Pollut. 1997, 95, 293-302.

(7) Vaněk, A.; Komárek, M.; Vokurková, P.; Mihaljevič, M.; Šebek, O.; Panušková, G.; Chrastný, V.; Drábek, O. Effect of illite and birnessite on thallium retention and bioavailability in contaminated soils. J. Hazard. Mater. 2011, 191, 170-176.

(8) Voegelin, A.; Pfenninger, N.; Petrikis, J.; Majzlan, J.; Plötze, M.; Senn, A. C.; Mangold, S.; Steininger, R.; Göttlicher, J. Thallium speciation and extractability in a thallium- and arsenic-rich soil developed from mineralized carbonate rock. Environ. Sci. Technol. 2015, 49, 5390-5398.

(9) Huangfu, X.; Jiang, J.; Lu, X.; Wang, Y.; Liu, Y.; Pang, S.-Y.; Cheng, H.; Zhang, X.; Ma, J. Adsorption and oxidation of thallium(I) by a nanosized manganese dioxide. Water, Air, Soil Pollut. 2015, 226, 2272.

(10) Wan, S.; Ma, M.; Lv, L.; Qian, L.; Xu, S.; Xue, Y.; Ma, Z. Selective capture of thallium(I) ion from aqueous solutions by amorphous hydrous manganese dioxide. Chem. Eng. J. 2014, 239, 200-206.

(11) Peacock, C. L.; Moon, E. M. Oxidative scavenging of thallium by birnessite: Explanation for thallium enrichment and stable isotope fractionation in marine ferromanganese precipitates. Geochim. Cosmochim. Acta 2012, 84, 297-313.

(12) Rehkämper, M.; Frank, M.; Hein, J. R.; Halliday, A. Cenozoic marine geochemistry of thallium deduced from isotopic studies of ferromanganese crusts and pelagic sediments. Earth Planet. Sci. Lett. 2004, 219, 77-91.

(13) Rehkämper, M.; Nielsen, S. G. The mass balance of dissolved thallium in the oceans. Mar. Chem. 2004, 85, 125-139.

(14) Wick, S.; Baeyens, B.; Marques Fernandes, M.; Voegelin, A. Thallium adsorption onto illite. Environ. Sci. Technol. 2017, 52, 571580 .

(15) Heinrichs, H.; Schulz-Dobrick, B.; Wedepohl, K. H. Terrestrial geochemistry of $\mathrm{Cd}, \mathrm{Bi}, \mathrm{Tl}, \mathrm{Pb}, \mathrm{Zn}$ and $\mathrm{Rb}$. Geochim. Cosmochim. Acta $1980,44,1519-1533$

(16) Jović, V. Thallium in rocks, soils and plants - past progress and future-needs. Neues Jahrbuch für Mineralogie-Abhandlungen 1993, 166, $43-52$.

(17) Radtke, A. S.; Dickson, F. W.; Slack, J. F. Occurrence and formation of avicennite, $\mathrm{Tl}_{2} \mathrm{O}_{3}$, as a secondary mineral at Carlin Gold Deposit, Nevada. J. Res. U.S. Geol. Surv. 1978, 6, 241-246.

(18) Crittenden, M. D.; Cuttitta, F.; Rose, H. J.; Fleischer, M. Studies on manganese oxide minerals. 6 . Thallium in some manganese oxides. Am. Mineral. 1962, 47, 1461-1467.

(19) Tebo, B. M.; Bargar, J. R.; Clement, B. G.; Dick, G. J.; Murray, K. J.; Parker, D.; Verity, R.; Webb, S. M. Biogenic manganese oxides: Properties and mechanisms of formation. Annu. Rev. Earth Planet. Sci. 2004, 32, 287-328.

(20) Post, J. E. Manganese oxide minerals: crystal structures and economic and environmental significance. Proc. Natl. Acad. Sci. U. S. A. 1999, 96, 3447-3454.

(21) Villalobos, M.; Toner, B.; Bargar, J.; Sposito, G. Characterization of the manganese oxide produced by Pseudomonas putida strain MnB1. Geochim. Cosmochim. Acta 2003, 67, 2649-2662.

(22) Bidoglio, G.; Gibson, P. N.; O'Gorman, M.; Roberts, K. J. X-ray absorption spectroscopy investigation of surface redox transformations of thallium and chromium on colloidal mineral oxides. Geochim. Cosmochim. Acta 1993, 57, 2389-2394.

(23) Cruz-Hernández, Y.; Villalobos, M.; Marcus, M. A.; Pi-Puig, T.; Zanella, R.; Martínez-Villegas, N. Tl(I) sorption behavior on birnessite and its implications for mineral structural changes. Geochim. Cosmochim. Acta 2019, 248, 356-369.

(24) Balgooyen, S.; Alaimo, P. J.; Remucal, C. K.; Ginder-Vogel, M. Structural transformation of $\mathrm{MnO}_{2}$ during the oxidation of Bisphenol A. Environ. Sci. Technol. 2017, 51, 6053-6062.

(25) Flynn, E. D.; Catalano, J. G. Reductive transformations of layered manganese oxides by small organic acids and the fate of trace metals. Geochim. Cosmochim. Acta 2019, 250, 149-172. 
(26) Wang, Q.; Yang, P.; Zhu, M. Structural transformation of birnessite by fulvic acid under anoxic conditions. Environ. Sci. Technol. 2018, 52, 1844-1853.

(27) Wang, Q.; Yang, P.; Zhu, M. Effects of metal cations on coupled birnessite structural transformation and natural organic matter adsorption and oxidation. Geochim. Cosmochim. Acta 2019, 250, 292-310.

(28) Elzinga, E. J. Reductive transformation of birnessite by aqueous Mn(II). Environ. Sci. Technol. 2011, 45, 6366-6372.

(29) Elzinga, E. J.; Kustka, A. B. A Mn-54 Radiotracer study of Mn isotope solid-liquid exchange during reductive transformation of vernadite $\left(\delta-\mathrm{MnO}_{2}\right)$ by aqueous $\mathrm{Mn}(\mathrm{II})$. Environ. Sci. Technol. 2015, 49, 4310-4316.

(30) Lafferty, B. J.; Ginder-Vogel, M.; Sparks, D. L. Arsenite oxidation by a poorly crystalline manganese-oxide 1 . Stirred-flow experiments. Environ. Sci. Technol. 2010, 44, 8460-8466.

(31) Lafferty, B. J.; Ginder-Vogel, M.; Zhu, M.; Livi, K. J. T.; Sparks, D. L. Arsenite oxidation by a poorly crystalline manganese-oxide. 2 . Results from X-ray absorption spectroscopy and X-ray diffraction. Environ. Sci. Technol. 2010, 44, 8467-8472.

(32) Holguera, J. G.; Etui, I. D.; Jensen, L. H. S.; Peña, J. Contaminant loading and competitive access of $\mathrm{Pb}, \mathrm{Zn}$ and $\mathrm{Mn}(\mathrm{III})$ to vacancy sites in biogenic $\mathrm{MnO}_{2}$. Chem. Geol. 2018, 502, 76-87.

(33) Lefkowitz, J. P.; Elzinga, E. J. Structural alteration of hexagonal birnessite by aqueous $\mathrm{Mn}(\mathrm{II})$ : Impacts on $\mathrm{Ni}(\mathrm{II})$ sorption. Chem. Geol. 2017, 466, 524-532.

(34) Peña, J.; Bargar, J. R.; Sposito, G. Copper sorption by the edge surfaces of synthetic birnessite nanoparticles. Chem. Geol. 2015, 396, 196-207.

(35) Shaikh, N.; Taujale, S.; Zhang, H.; Artyushkova, K.; Ali, A. M. S.; Cerrato, J. M. Spectroscopic investigation of interfacial interaction of manganese oxide with triclosan, aniline, and phenol. Environ. Sci. Technol. 2016, 50, 10978-10987.

(36) Simanova, A. A.; Kwon, K. D.; Bone, S. E.; Bargar, J. R.; Refson, K.; Sposito, G.; Peña, J. Probing the sorption reactivity of the edge surfaces in birnessite nanoparticles using nickel(II). Geochim. Cosmochim. Acta 2015, 164, 191-204.

(37) Simanova, A. A.; Peña, J. Time-resolved investigation of cobalt oxidation by $\mathrm{Mn}(\mathrm{III})$-rich $\delta$ - $\mathrm{MnO}_{2}$ using quick X-ray absorption spectroscopy. Environ. Sci. Technol. 2015, 49, 10867-10876.

(38) Yang, P.; Post, J. E.; Wang, Q.; Xu, W.; Geiss, R.; McCurdy, P. R.; Zhu, M. Metal adsorption controls stability of layered manganese oxides. Environ. Sci. Technol. 2019, 53, 7453-7462.

(39) Atkins, A. L.; Shaw, S.; Peacock, C. L. Nucleation and growth of todorokite from birnessite: Implications for trace-metal cycling in marine sediments. Geochim. Cosmochim. Acta 2014, 144, 109-125.

(40) Bodeï, S.; Manceau, A.; Geoffroy, N.; Baronnet, A.; Buatier, M. Formation of todorokite from vernadite in Ni-rich hemipelagic sediments. Geochim. Cosmochim. Acta 2007, 71, 5698-5716.

(41) Feng, X. H.; Zhu, M.; Ginder-Vogel, M.; Ni, C.; Parikh, S. J.; Sparks, D. L. Formation of nano-crystalline todorokite from biogenic Mn oxides. Geochim. Cosmochim. Acta 2010, 74, 3232-3245.

(42) Golden, D. C.; Chen, C. C.; Dixon, J. B. Synthesis of todorokite. Science 1986, 231, 717-719.

(43) Golden, D. C.; Chen, C. C.; Dixon, J. B. Transformation of birnessite to buserite, todorokite, and manganite under mild hydrothermal treatment. Clays Clay Miner. 1987, 35, 271-280.

(44) DeGuzman, R. N.; Shen, Y.-F.; Neth, E. J.; Suib, S. L.; O'young, C. L.; Levine, S.; Newsam, J. M. Synthesis and characterization of octahedral molecular-sieves (OMS-2) having the hollandite structure. Chem. Mater. 1994, 6, 815-821.

(45) Grangeon, S.; Fernandez-Martinez, A.; Warmont, F.; Gloter, A.; Marty, N.; Poulain, A.; Lanson, B. Cryptomelane formation from nanocrystalline vernadite precursor: a high energy X-ray scattering and transmission electron microscopy perspective on reaction mechanisms. Geochem. Trans. 2015, 16, 12.

(46) Liu, J.; Makwana, V.; Cai, J.; Suib, S. L.; Aindow, M. Effects of alkali metal and ammonium cation templates on nanofibrous cryptomelane-type manganese oxide octahedral molecular sieves (OMS-2). J. Phys. Chem. B 2003, 107, 9185-9194.

(47) Parc, S.; Nahon, D.; Tardy, Y.; Vieillard, P. Estimated solubility products and fields of stability for cryptomelane, nsutite, birnessite, and lithiophorite based on natural lateritic weathering sequences. Am. Mineral. 1989, 74, 466-475.

(48) Marafatto, F. F.; Lanson, B.; Peña, J. Crystal growth and aggregation in suspensions of $\delta-\mathrm{MnO}_{2}$ nanoparticles: Implications for surface reactivity. Environ. Sci. Nano 2018, 5, 497-508.

(49) Feng, Q.; Kanoh, H.; Miyai, Y.; Ooi, K. Metal ion extraction/ insertion reactions with todorokite-type manganese oxide in the aqueous phase. Chem. Mater. 1995, 7, 1722-1727.

(50) McKenzie, R. M. The Synthesis of birnessite, cryptomelane, and some other oxides and hydroxides of manganese. Mineral. Mag. 1971, 38, 493-502.

(51) Liu, M. M.; Cao, X. H.; Tan, W. F.; Feng, X. H.; Qiu, G. H.; Chen, X. H.; Liu, F. Structural controls on the catalytic polymerization of hydroquinone by birnessites. Clays Clay Miner. 2011, 59, 525-537.

(52) Shindo, H.; Huang, P. M. Catalytic effects of manganese (IV), iron(III), aluminum, and silicon oxides on the formation of phenolic polymers ${ }^{1}$. Soil Sci. Soc. Am. J. 1984, 48, 927-934.

(53) Villinski, J. E.; O’Day, P. A.; Corley, T. L.; Conklin, M. H. In situ spectroscopic and solution analyses of the reductive dissolution of $\mathrm{MnO}_{2}$ by $\mathrm{Fe}(\mathrm{II})$. Environ. Sci. Technol. 2001, 35, 1157-1163.

(54) Grangeon, S.; Manceau, A.; Guilhermet, J.; Gaillot, A. C.; Lanson, M.; Lanson, B. Zn sorption modifies dynamically the layer and interlayer structure of vernadite. Geochim. Cosmochim. Acta 2012, $85,302-313$.

(55) Lingane, J. J.; Karplus, R. New method for determination of manganese. Ind. Eng. Chem., Anal. Ed. 1946, 18, 191-194.

(56) Vetter, K. J.; Jaeger, N. Potentialausbildung an der Mangandioxid-Elektrode als Oxidelektrode mit nichtstöchiometrischem Oxid. Electrochim. Acta 1966, 11, 401-419.

(57) Ravel, B.; Newville, M. ATHENA, ARTEMIS, HEPHAESTUS: data analysis for X-ray absorption spectroscopy using IFEFFIT. $J$ Synchrotron Radiat. 2005, 12, 537-541.

(58) Elzinga, E. J. ${ }^{54} \mathrm{Mn}$ radiotracers demonstrate continuous dissolution and reprecipitation of vernadite $\left(\delta-\mathrm{MnO}_{2}\right)$ during interaction with aqueous $\mathrm{Mn}(\mathrm{II})$. Environ. Sci. Technol. 2016, 50, 8670-8677.

(59) Zwicker, W. K.; Meijer, W. O. J.; Jaffe, H. W. Nsutite-a widespread manganese oxide mineral. Am. Mineral. 1962, 47, 246266.

(60) Hem, J. D. Redox processes at surfaces of manganese oxide and their effects on aqueous metal ions. Chem. Geol. 1978, 21, 199-218.

(61) Luo, Y.; Tan, W.; Suib, S. L.; Qiu, G.; Liu, F. Dissolution and phase transformation processes of hausmannite in acidic aqueous systems under anoxic conditions. Chem. Geol. 2018, 487, 54-62.

(62) Manceau, A.; Lanson, B.; Drits, V. A. Structure of heavy metal sorbed birnessite. Part III: Results from powder and polarized extended X-ray absorption fine structure spectroscopy. Geochim. Cosmochim. Acta 2002, 66, 2639-2663.

(63) Otto, H. H.; Baltrusch, R.; Brandt, H. J. Further evidence for $\mathrm{Tl}^{3+}$ in Tl-based superconductors from improved bond strength parameters involving new structural data of cubic $\mathrm{Tl}_{2} \mathrm{O}_{3}$. Phys. C 1993, 215, 205-208.

(64) Blixt, J.; Glaser, J.; Mink, J.; Persson, I.; Persson, P.; Sandstroem, M. Structure of thallium(III) chloride, bromide, and cyanide complexes in aqueous-solution. J. Am. Chem. Soc. 1995, 117, 5089-5104.

(65) Villalobos, M.; Bargar, J.; Sposito, G. Mechanisms of $\mathrm{Pb}(\mathrm{II}$ ) sorption on a biogenic manganese oxide. Environ. Sci. Technol. 2005, 39, 569-576.

(66) Manceau, A.; Marcus, M. A.; Grangeon, S.; Lanson, M.; Lanson, B.; Gaillot, A. C.; Skanthakumar, S.; Soderholm, L. Shortrange and long-range order of phyllomanganate nanoparticles determined using high-energy X-ray scattering. J. Appl. Crystallogr. 2013, 46, 193-209. 
(67) Villalobos, M.; Lanson, B.; Manceau, A.; Toner, B.; Sposito, G. Structural model for the biogenic $\mathrm{Mn}$ oxide produced by Pseudomonas putida. Am. Mineral. 2006, 91, 489-502.

(68) Yu, Q.; Ohnuki, T.; Kozai, N.; Sakamoto, F.; Tanaka, K.; Sasaki, K. Quantitative analysis of radiocesium retention onto birnessite and todorokite. Chem. Geol. 2017, 470, 141-151.

(69) Yu, Q.; Tanaka, K.; Kozai, N.; Sakamoto, F.; Tani, Y.; Ohnuki, T. Adsorption of Cs onto biogenic birnessite: effects of layer structure, ionic strength, and competition cations. ACS Earth Space Chem. 2018, 2, 797-810.

(70) Lopano, C. L.; Heaney, P. J.; Post, J. E. Cs-exchange in birnessite: Reaction mechanisms inferred from time-resolved X-ray diffraction and transmission electron microscopy. Am. Mineral. 2009, 94, 816-826.

(71) Lopano, C. L.; Heaney, P. J.; Bandstra, J. Z.; Post, J. E.; Brantley, S. L. Kinetic analysis of cation exchange in birnessite using time-resolved synchrotron X-ray diffraction. Geochim. Cosmochim. Acta 2011, 75, 3973-3981.

(72) Tsuji, M.; Komarneni, S.; Tamaura, Y.; Abe, M. Cationexchange properties of a layered manganic acid. Mater. Res. Bull. 1992, 27, 741-751.

(73) Tsuji, M.; Komarneni, S. Powder x-Ray diffraction study of a cryptomelane-type manganic acid and its alkali cation exchanged forms. J. Mater. Res. 1993, 8, 3145-3150.

(74) Tsuji, M.; Komarneni, S.; Abe, M. Ion-exchange selectivity for alkali-metal ions on a cryptomelane-type hydrous manganese-dioxide. Solvent Extr. Ion Exch. 1993, 11, 143-158.

(75) Liu, J.; Lippold, H.; Wang, J.; Lippmann-Pipke, J.; Chen, Y. Sorption of thallium(I) onto geological materials: Influence of $\mathrm{pH}$ and humic matter. Chemosphere 2011, 82, 866-871.

(76) Casiot, C.; Egal, M.; Bruneel, O.; Verma, N.; Parmentier, M.; Elbaz-Poulichet, F. Predominance of aqueous $\mathrm{Tl}(\mathrm{I})$ species in the river system downstream from the abandoned Carnoulès Mine (Southern France). Environ. Sci. Technol. 2011, 45, 2056-2064.

(77) Yang, P.; Lee, S.; Post, J. E.; Xu, H.; Wang, Q.; Xu, W.; Zhu, M. Trivalent manganese on vacancies triggers rapid transformation of layered to tunneled manganese oxides (TMOs): Implications for occurrence of TMOs in low-temperature environment. Geochim. Cosmochim. Acta 2018, 240, 173-190.

(78) van Genuchten, C. M.; Peña, J. Sorption selectivity of birnessite particle edges: a d-PDF analysis of $\mathrm{Cd}(\mathrm{II})$ and $\mathrm{Pb}(\mathrm{II})$ sorption by $\delta$ $\mathrm{MnO}_{2}$ and ferrihydrite. Environ. Sci.: Processes Impacts 2016, 18, 1030-1041.

(79) Koschinsky, A.; Hein, J. R. Uptake of elements from seawater by ferromanganese crusts: solid-phase associations and seawater speciation. Mar. Geol. 2003, 198, 331-351.

(80) Rehkämper, M.; Frank, M.; Hein, J. R.; Porcelli, D.; Halliday, A.; Ingri, J.; Liebetrau, V. Thallium isotope variations in seawater and hydrogenetic, diagenetic, and hydrothermal ferromanganese deposits. Earth Planet. Sci. Lett. 2002, 197, 65-81.

(81) Coup, K. M.; Swedlund, P. J. Demystifying the interfacial aquatic geochemistry of thallium(I): New and old data reveal just a regular cation. Chem. Geol. 2015, 398, 97-103. 